\title{
موقع السلطة التقديرية في أركان القرار الإداري
}

\author{
دكتور \\ محمد عبد اللّه الشوابـورة \\ استاذ القانوز العام المساعد \\ جامعة ظفار - سلطنة عُمان \\ كلية الآداب والعلوم التطبيقية \\ قسم الحقوق
}





\section{|ll|}

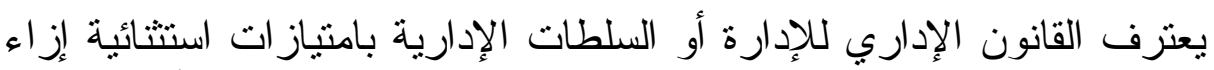

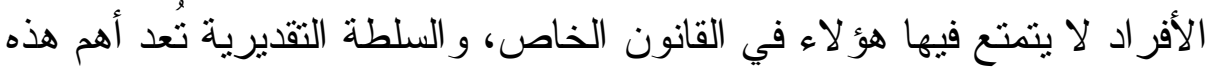

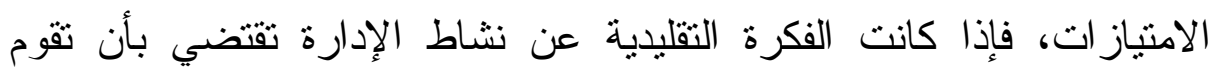

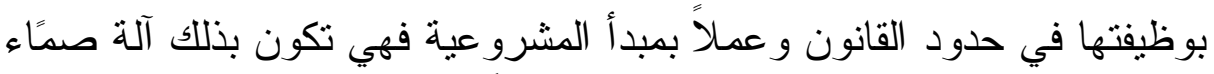

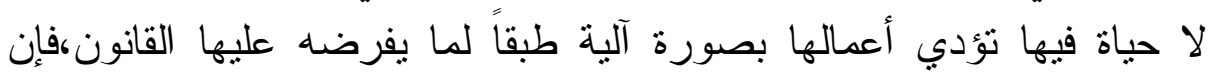

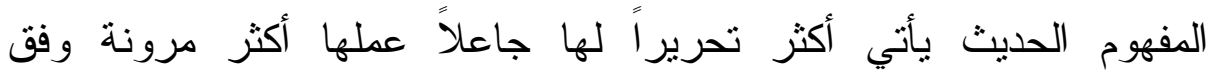

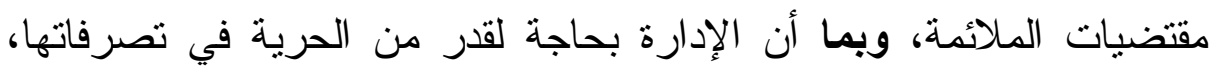

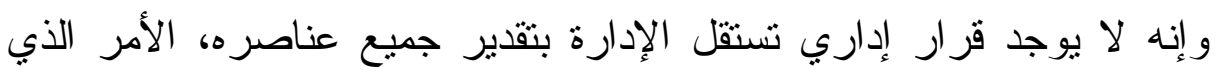

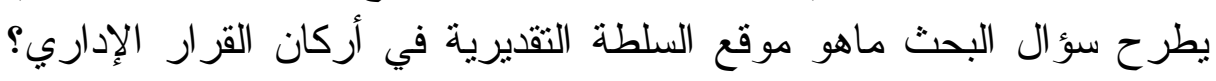

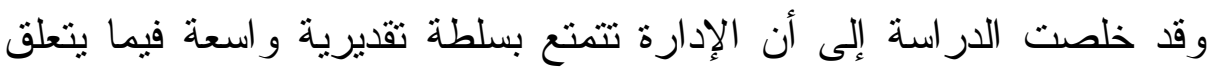

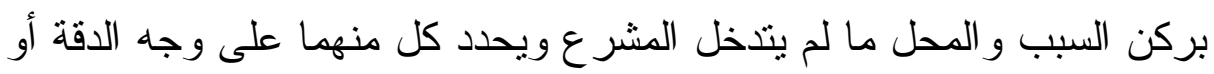
يتذخل القاضي ويفرض رقابته على اختيار السبب و المحل لاعتبار ات يقدرها بنفسه، أما ركن الاختصاص وركن الثكل وركن الغاية فلا مجال لسلطة الإدارة التقديرية فيها. ومما يجعل من هذا البحث مجالاً خصباً للار اسة و التقييم استخدمت فيه مناهج

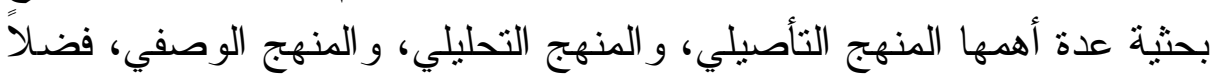

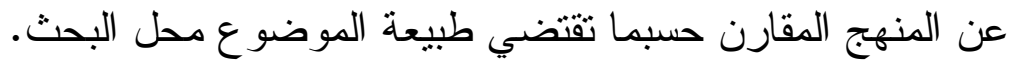
وقد قسمنا هذا البحث إلى مبحث تمهيدي تتاولنا فيه الموقف الفقهي و القضائي من السلطة التقديرية وملأئمتها، وخمسة مطالب تتحدث عن موقع السلطة التقديرية في أركان القر ار الإداري. 


\section{Abstract}

Administrative law recognizes exceptional privileges for management and administrative authorities with regard to individuals, privileges that parties do not get through the private law. One of these privileges is the authority of discretion. If the role of the administration, as the traditional view goes, is only judge according to the jurisdiction of the law, following the principle of legitimacy, then it will be a blind machine that has no life in it that applies what the law dictates. In contrast, modern approach makes it more flexible according to the requirements of propriety, especially because management requires some freedom in its activities. Besides, there is no administrative decision that management takes on its own.

This approach triggers the question to be addressed in this paper: what is the place of description among the bases of administrative decision. The study has found that administration has a major authority of description with regard to cause and place unless the legislator intervenes and defines each of them specifically, or the judge interferes and forces his own view over deciding place and cause based on his own personal considerations. However, there is no place for description with regard to the factors of specialization, form, and purpose.

In this research, I have used several research methods such as rooting, analytical, descriptive and comparative as per the nature topic subject of discussion. The study includes a preliminary discussion on jurisprudence and judiciary stance on description and its suitability. It also discusses five sections that tackle the position of description as a basis for administrative decision. 


\section{مبحث تمهيدي}

لقد كتب "دي سوتو" يقول: إن موضوع الاختصاص يعطي فكرة عن الماهية الواقعية للحواجز التي تحيط بسلطة التصرف الإداداري المنفرد، و والسلطة

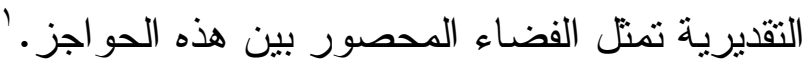
حيث يعترف القانون الإداري للإدارة أو السلطات الإدارية بامنياز ات استثنائية

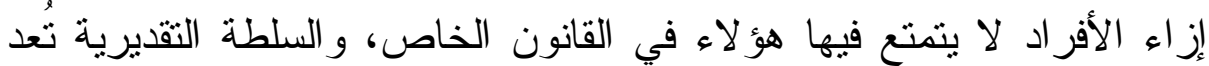

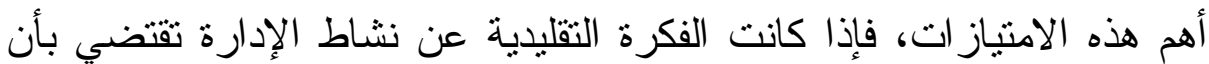

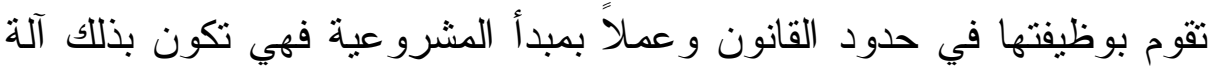

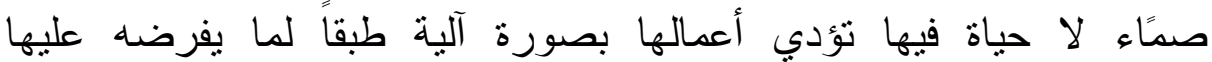

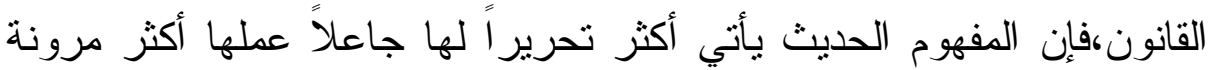

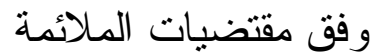
، ومن المعلوم بأن فكرة السلطة التقديرية للإدارة يرجع ظهور ها إلى تطور

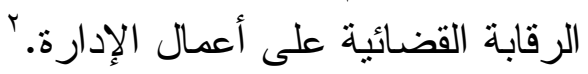

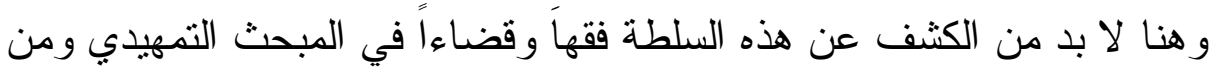

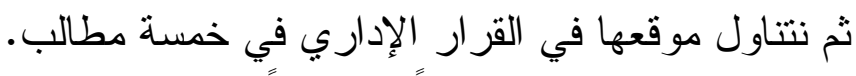

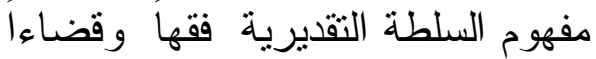
أو لاً: الموقف الفقهي من السلطة التقديرية: يقصد بالسلطة التقديرية أن الإدارة تجاه وقائع معينة حرية في اتخاذ قرار ما

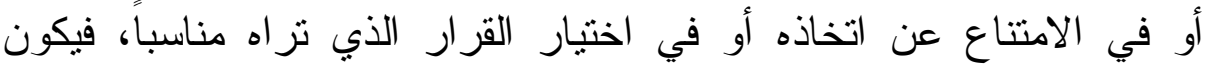

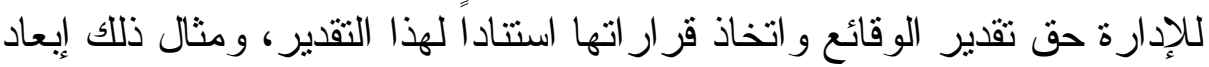

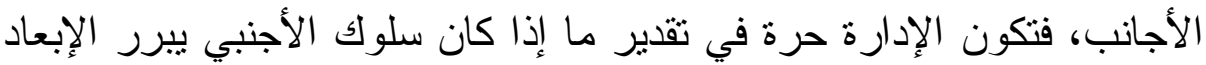
أم لا، وكذلك في حال منح الأوسمة، فيكون للإدارة سلطة فقديرية في في الإن المنح

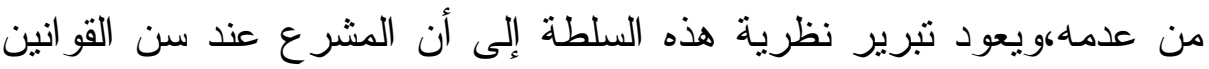

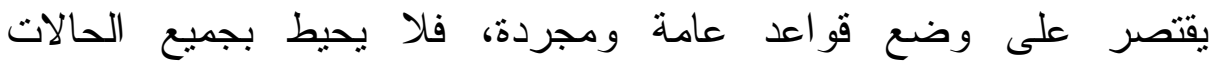
و الملابسات الخاصة التي تظهر عند تطبيق هذه القو اعد من جانب الإدارة،

Desoto, contribution a la Theorie des nullities des actes -' administratifs unilateraux, these paris, 1941.NO.121. كَ- د. عادل حسين فهيم،القوة التنفيذية للقرار الإداري،الدار القومية للطباعة و النشــر، دون

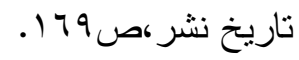


فكان لا بد من منح الإدارة أثناء مزاولة نشاطها حرية تقدير ملائمة العمل الذي تقوم فيه في بعض حقول اختصاصها، فهي تتمكن وحدها تقدير ظروف

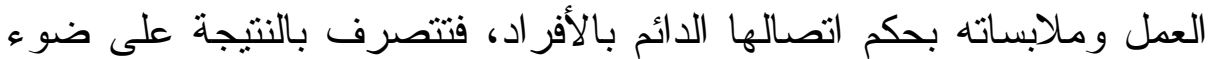
ذلك.

وقد حدد العميد "بونار" مفهوم السلطة التقديرية بقوله: تكون سلطة الإدارة

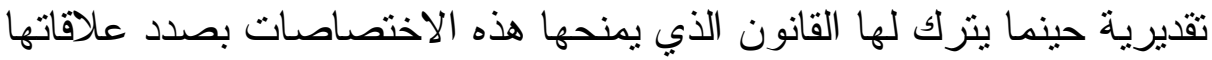

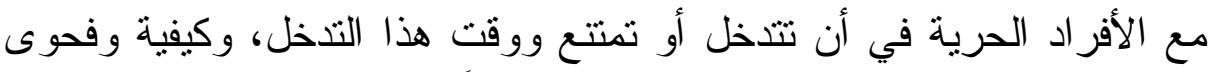
القرار الذي تتخذه، فالسلطة التقديرية تتحصر إذا في حرية التقدير التي يتركها

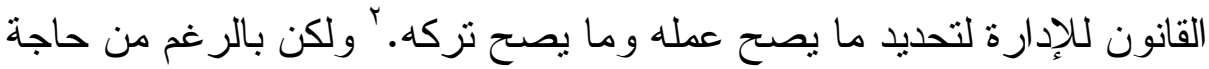

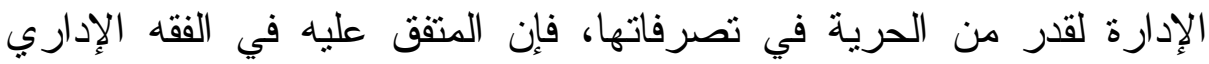

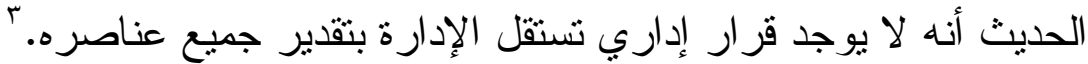

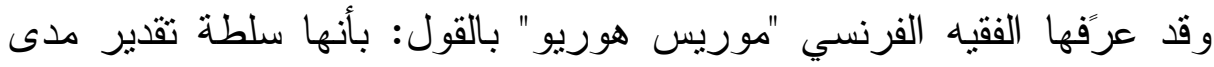

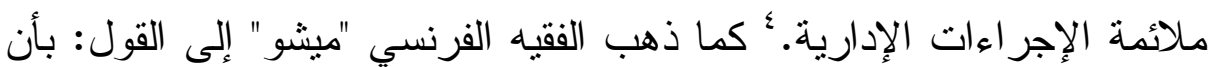

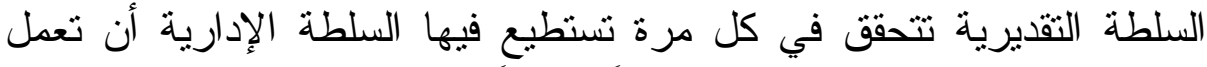

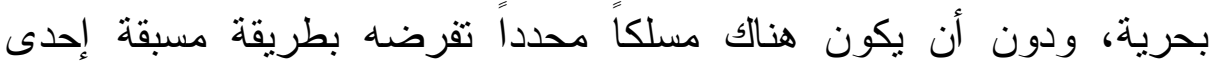

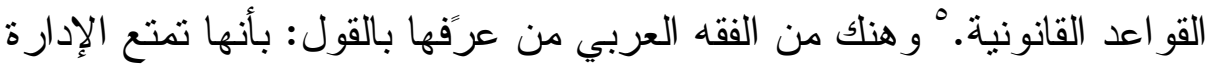
بقسط من حرية التصرف عندما تمارس اختصاصاتها القانونية بحيث يكون بإن

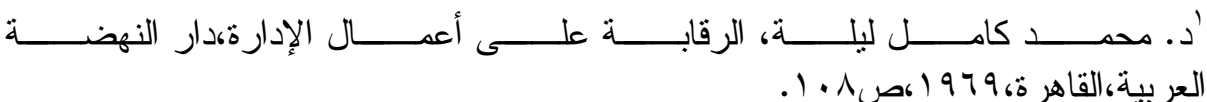

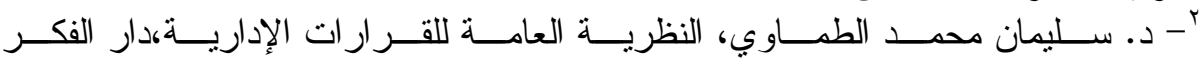

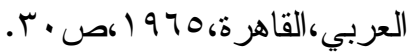
Jacqtif ueline Morand - Devili,Cours de droit administatif

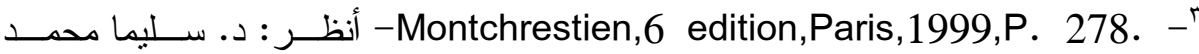

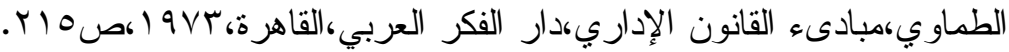

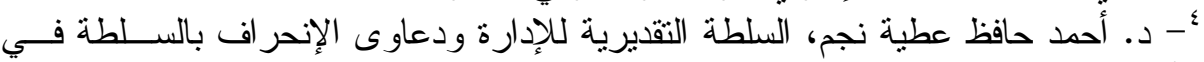

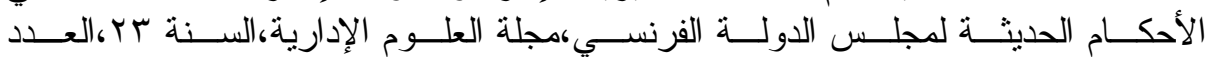

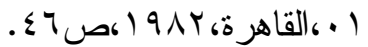

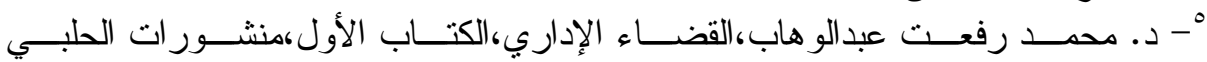

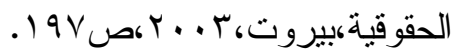


للإدارة تقدير اتخاذ التصرف أو الامتتاع عن اتخاذه على نحو معين أو اختيار

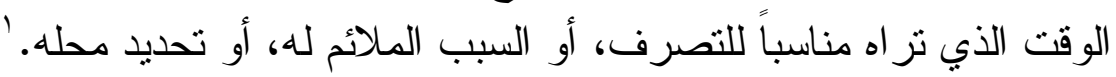
ونحن نذهب مع الفقهُ الذي يرى أن كافة التعريفات و المفاهيم التي أطلقت على السلطة التقديرية تتفق حول عناصر ومقومات هذه السلطة التقديرية

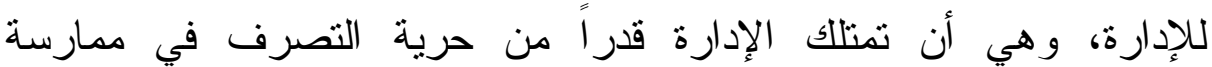

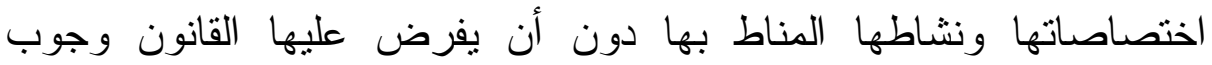

$$
\text { التصرف أنقاف على نحو معين. }
$$

ثانياً: الموقف القضائي والفقهي من السلطة التقديرية وملاعمتها:

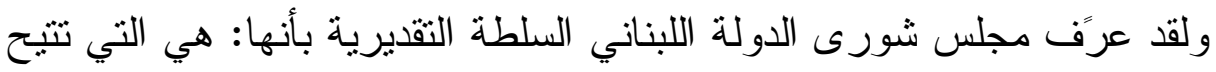

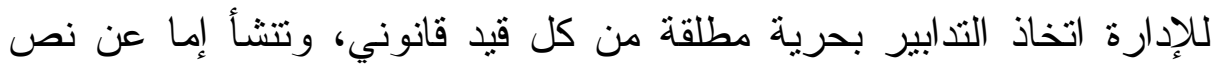

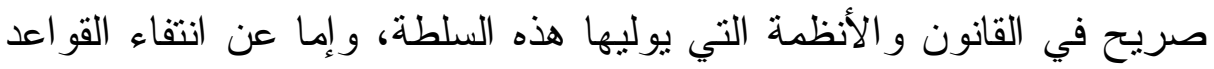
و الأحكام القانونية التي تحد من سلطتها التقديرية في ممارسة عملها الإداري. وتقوم السلطة التقديرية على أساس تمتع الإدارة بقسط من الحرية في مباشرة

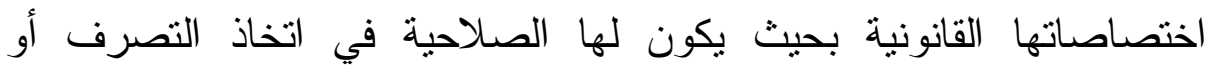

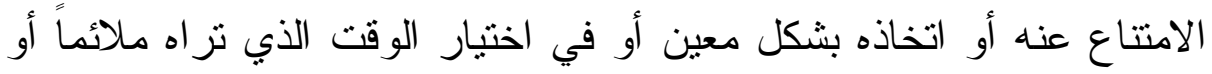
تحديد محله أو غايته، شريطة أن تتوخى الإدارة تحقيق الصالح العام حتى إذا لتصا

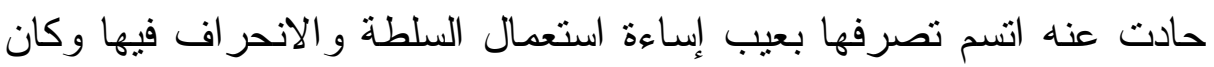

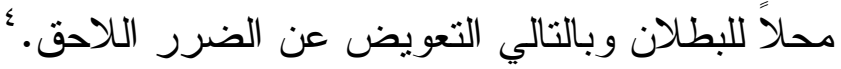

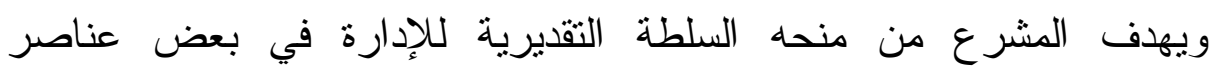
التصرف إلى غرس روح الابنكار والنشاط، الأمر الذي يؤدي إلى حسن الذهن ممارسة الوظيفة الإدارية، لأن المشرع لا لإنسطع أن ينظم تفاصيل الأعمال

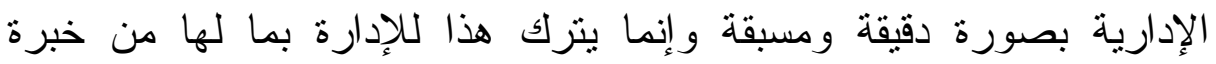

'- د. سامي جمال الدين، القضاء الإداري والرقابة علــى أعمــال الإدارة، دار الجامعـــة

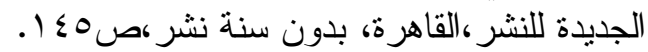

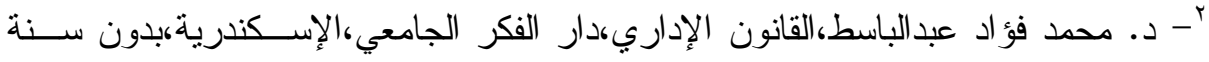

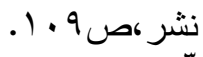

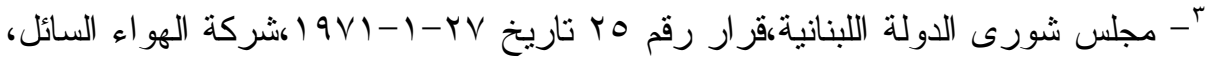

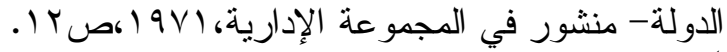

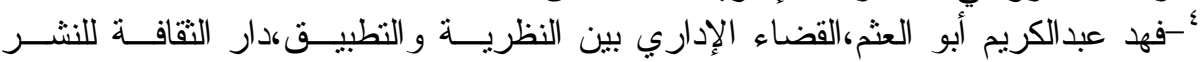

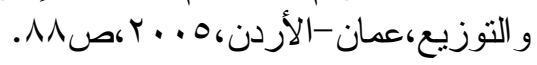


وتجارب، غير أن سلطة الإدارة التقديرية لا تمارسها دون ضابط، فهي تخضع

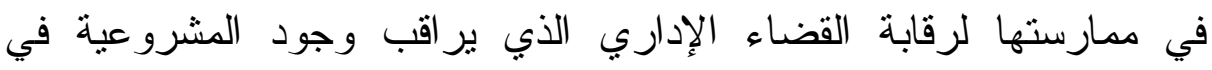

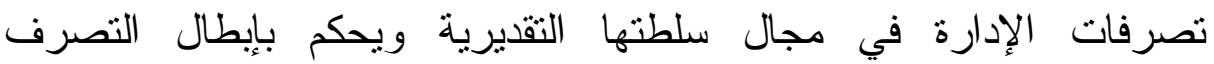

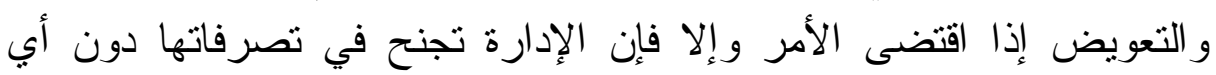

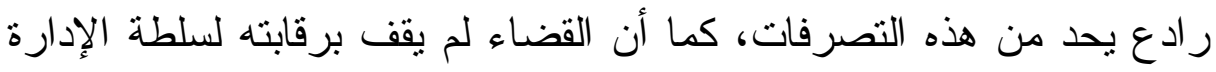

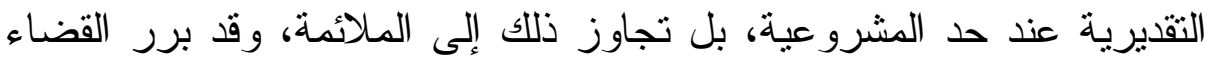

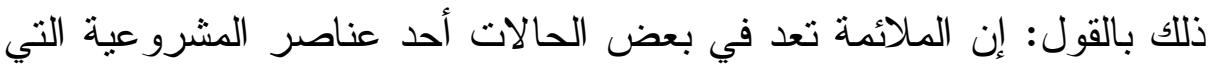

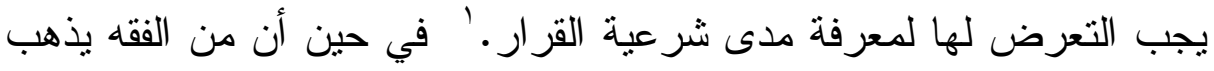

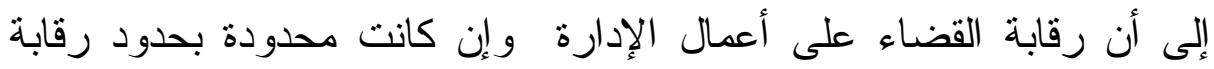

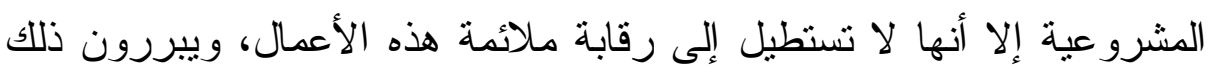

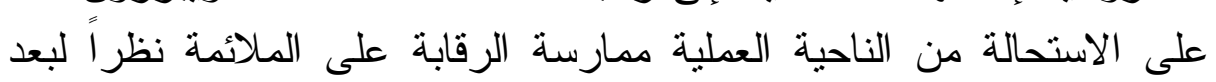

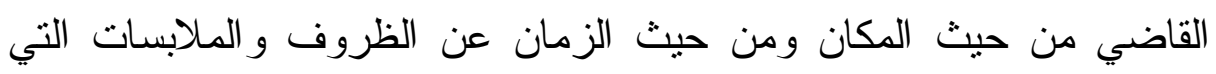
أحاطت بالإدارة في ممارستها لسلطتها التقديرية،وهن النمان الناحية القانونية الالتز ام بمبدأ الفصل بين السلطات لأن القاضي إذا تصدا تصدى لتقدير ملائمة العمل

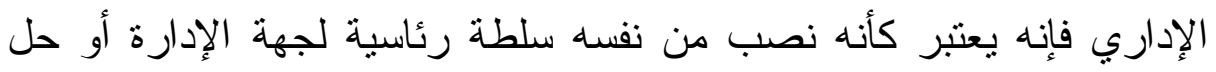

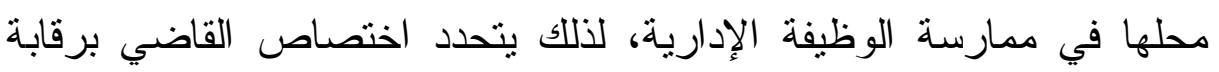

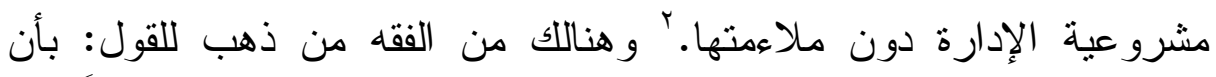
القضاء الإدارِي ليس قاضي مشرو عية فحسب بل أنه قاضي ملائمة أيضاً و أنه

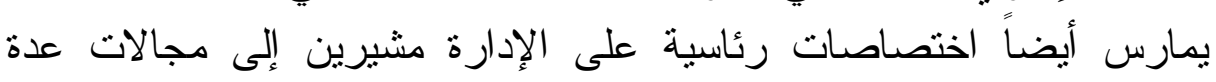
مارس فيها القضاء رقابة الملائمة خاصة في مجال تأديب الموظفين الإدين باعنبار

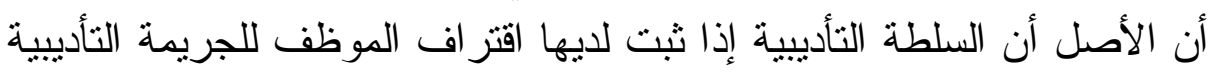

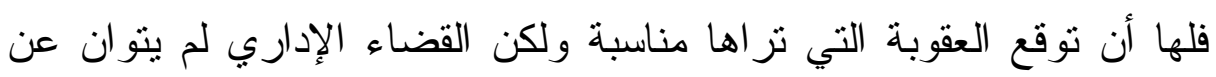
بسط رقابته على مدى ملائمة العقوبة المفروضة على الى الموظفة ولى فقد قرر

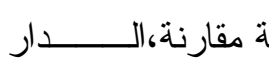

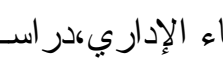

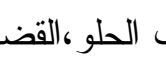
ر راغ

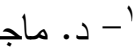

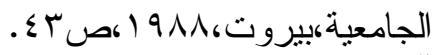

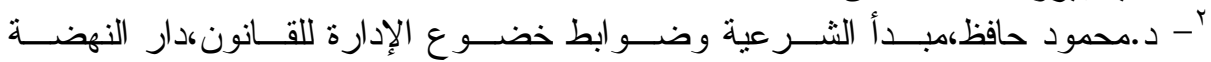

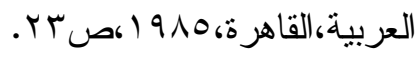


مجلس الدولة الفرنسي في 9 يونيو لسنة 19V^ "عدم النتاسب بالغ الوضوح بين خطورة الأخطاء المنسوبة للموظف و العقوبة الموقعة عليه".'

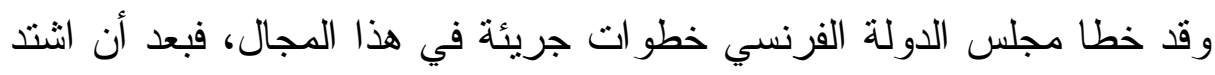
عوده وثبَت أركانه أقر لنفسه الحق في رقابة مدى أهمية وخطورة الوقائع التي

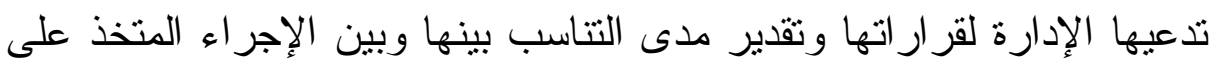
أساسها. وقد كان لمحكمة القضاء الإداري المصري العديد من القرار ات التي تسوغ

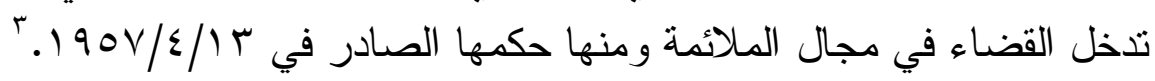

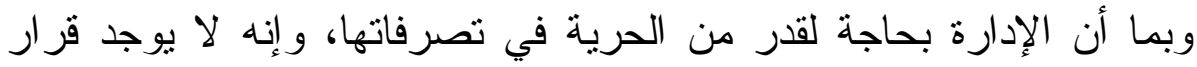

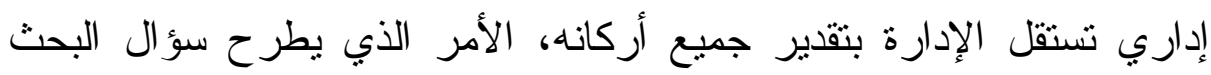

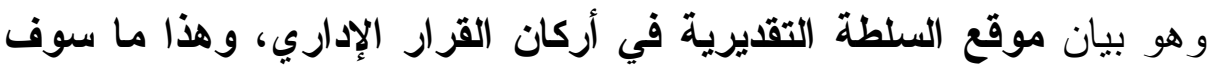

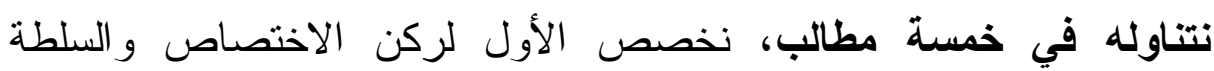
التقديرية، والمطلب الثاني لركن الثكل و السلطة التقديرية، و المطلب الثالث

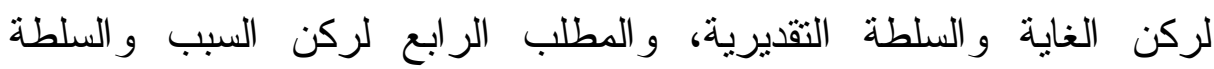
التقديرية، و المطلب الخامس لركن المحل و السلطة التقديرية.

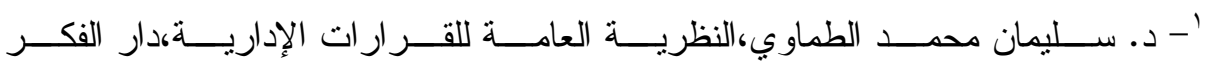

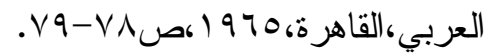

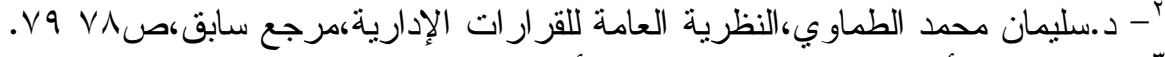

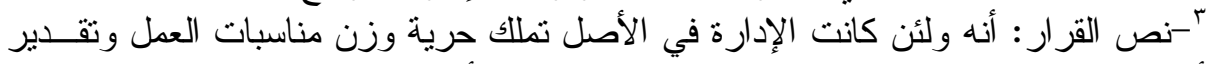

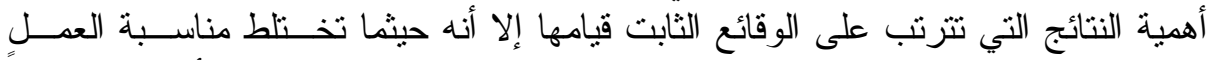

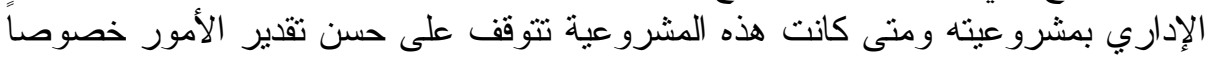

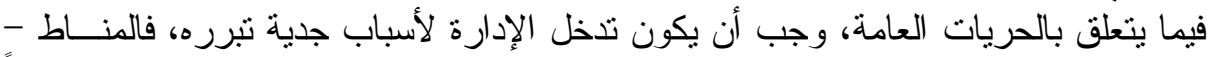

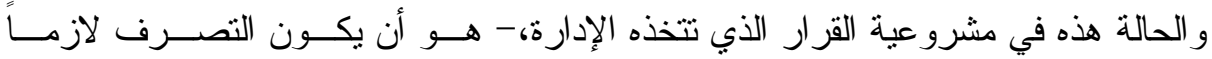

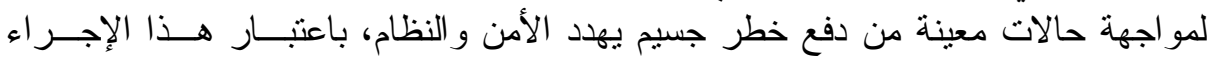

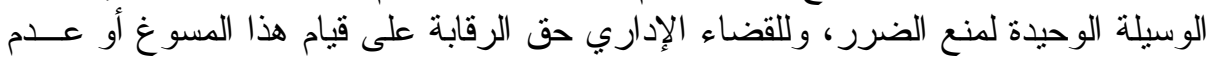

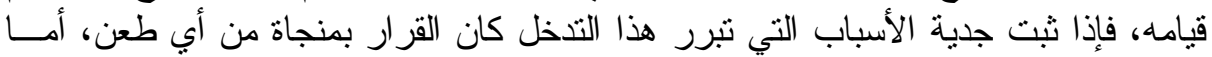

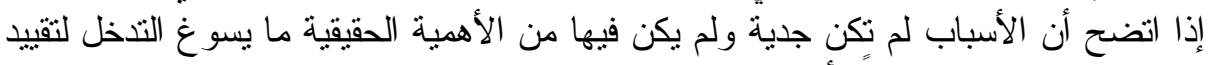

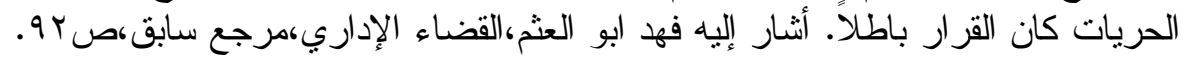




\section{المطاب الأول}

\section{ركن الافتصاص والسلطة التقديرية}

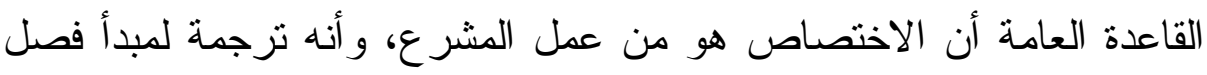

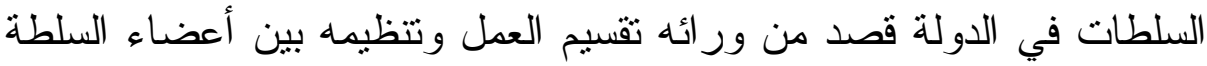

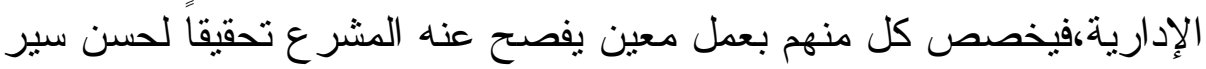

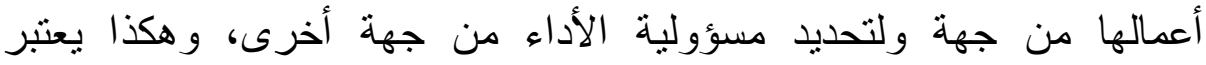

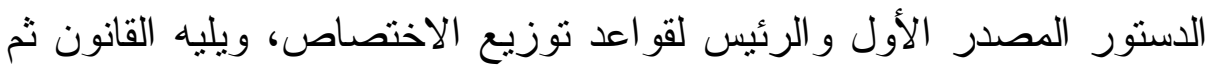

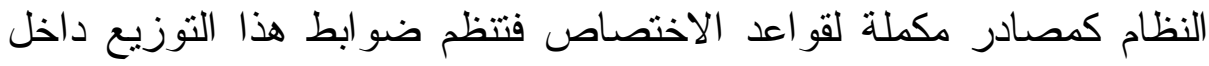

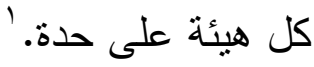

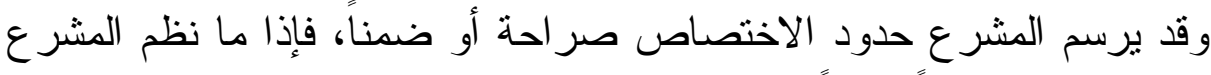

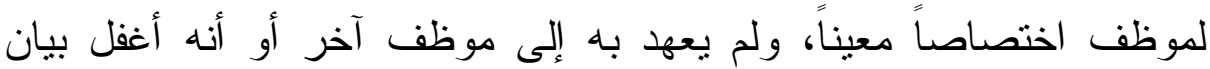

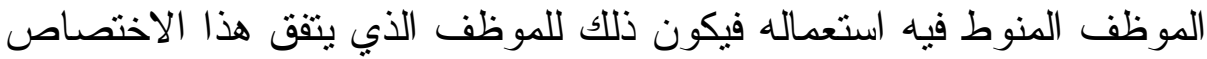

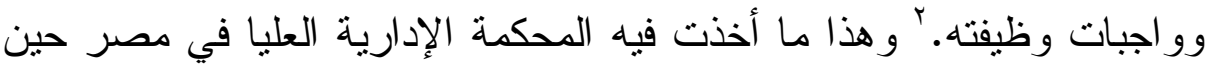

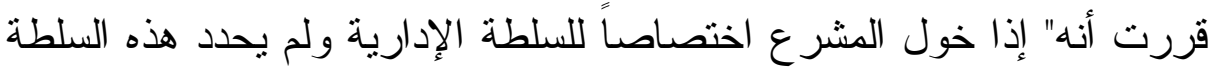

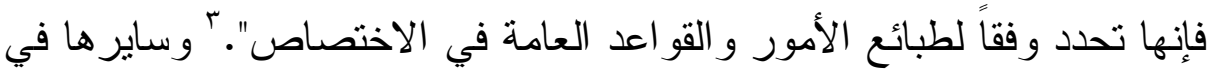

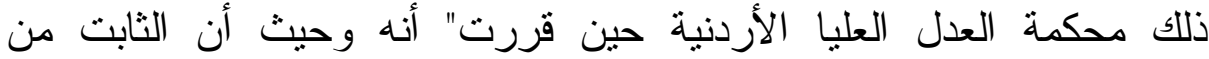

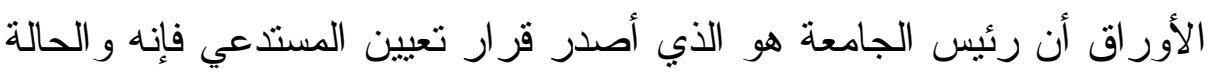

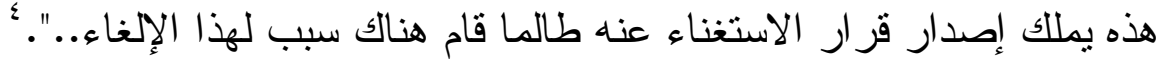

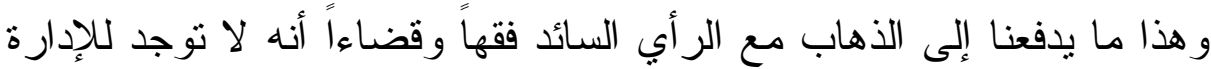

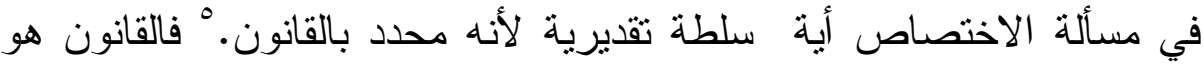

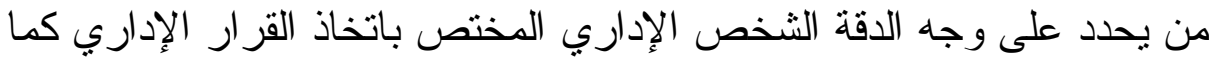

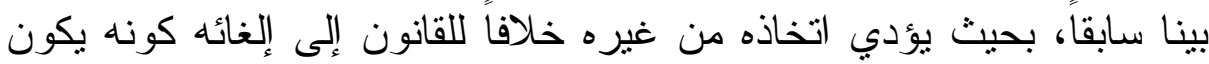

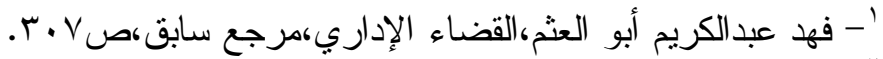

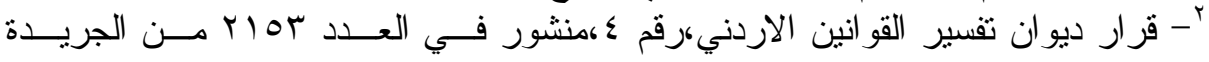

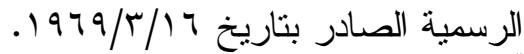
"

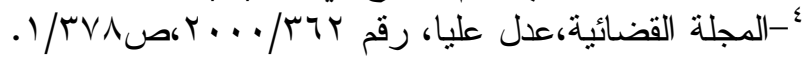

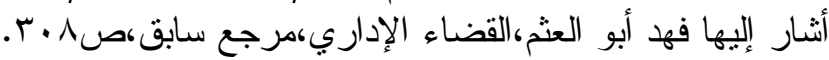

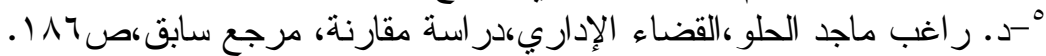


مشوباً بعيب عدم الإختصاص، أي عدم الأهلية القانونية لسلطة الإدارة في

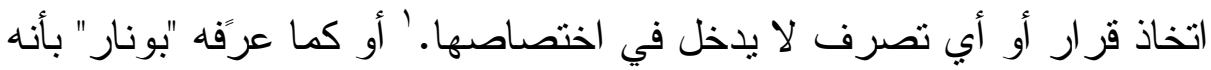

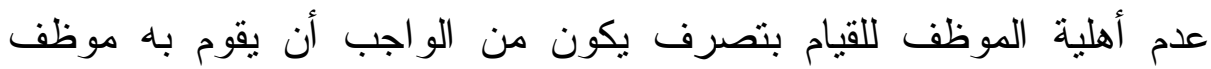
آخر ".ّ وهذا العيب يعد من النظام العام.

\section{الإطالب الثاني}

\section{ركن الشكل والسطبة التقديرية}

إن الأصل في القرارات الإدارية عدم اشتر اط صدور ها في صيغة أو شكل

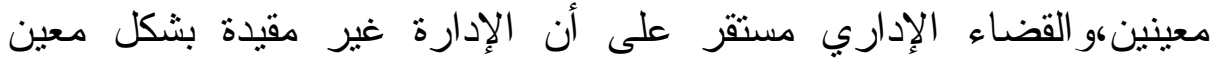

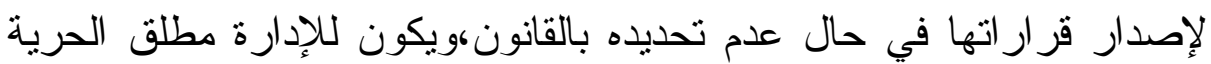

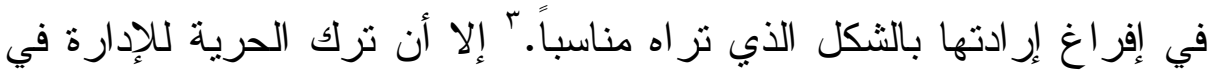

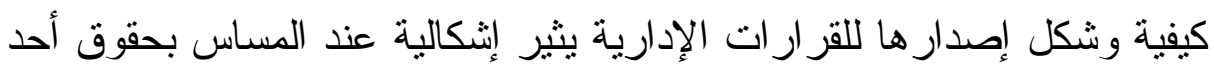

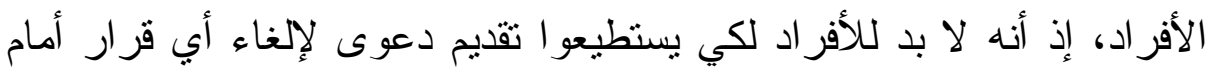

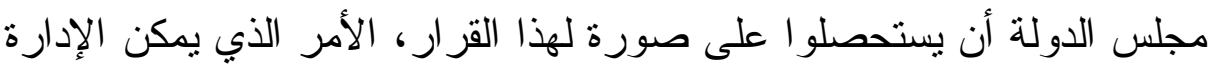

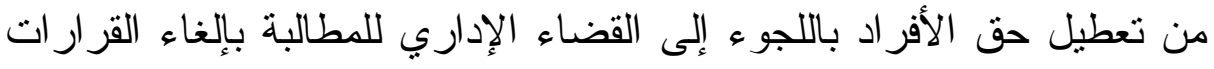

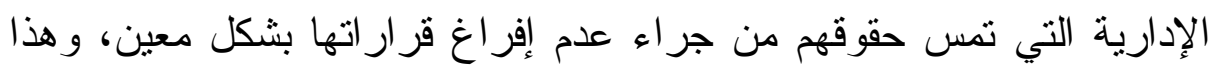

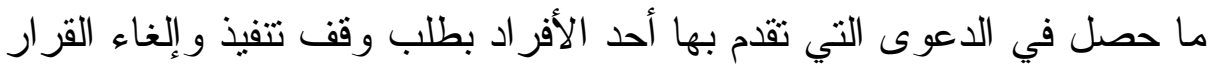
الصادر عن رئيس مجلس مدينة اللاذقية و المتضمن تشميع الثقتين العائدتين

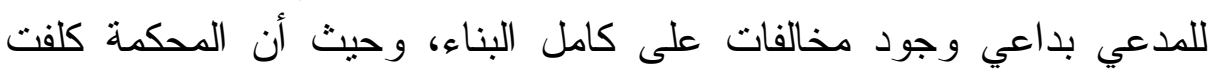

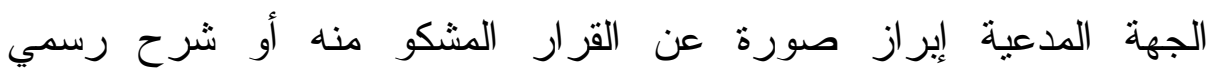
بمضمونه، إلا أن الجهة المدعية لم تتفذ تكليف المحكمة رغم إدما امهالها، الأمر الذي أدى لصدور قرار بعدم قبول الدعوى لعدم وجود قرار إدهة إداري قابل للطعن أمام مجلس الدولة بهيئة قضاء إداري.

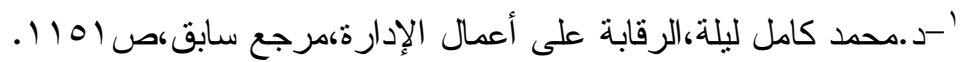

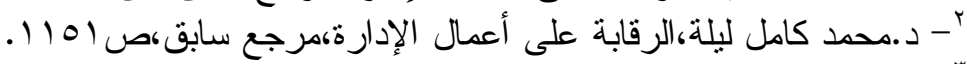

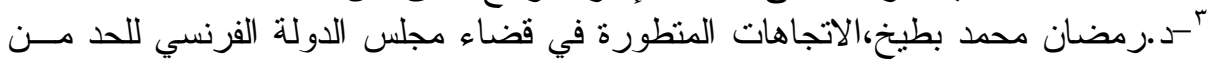

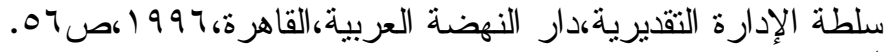

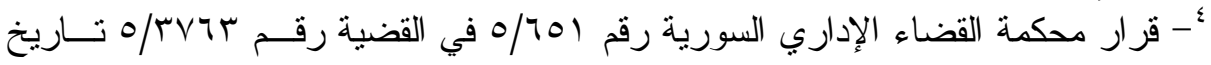

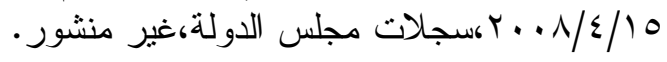




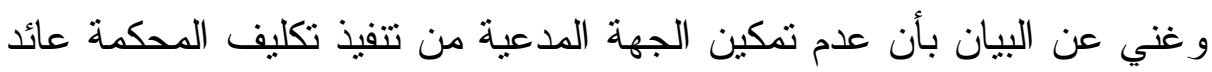

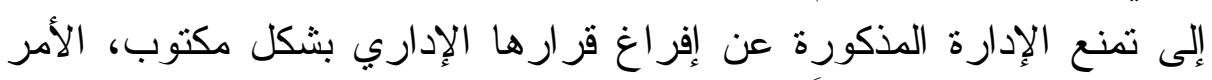

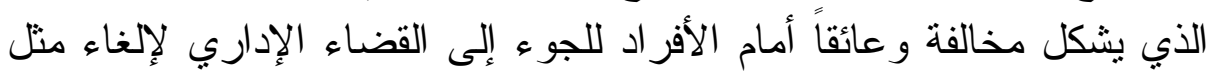

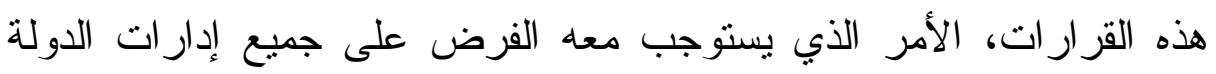

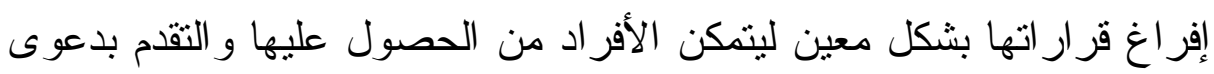

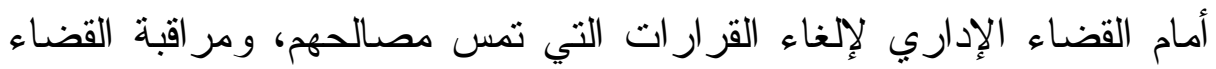

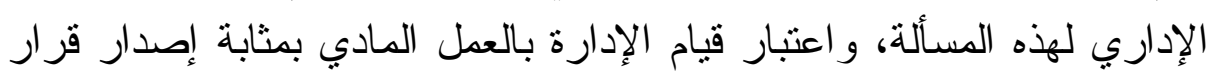
إداري. و لا بد من الإثارة إلى أنه يبقى للأفر اد عند قيام الإدارة بأي عمل مادي دون

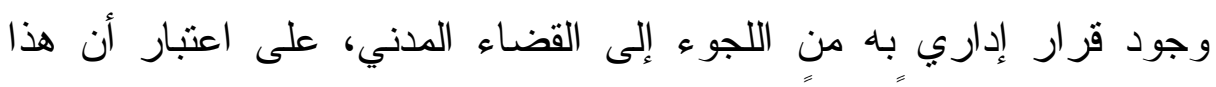

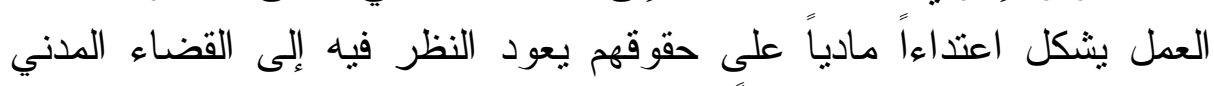
للتعويض عنه إذا سبب ضرراً، وقد جاء في قرار لمحكمة الاستئناف المدنية

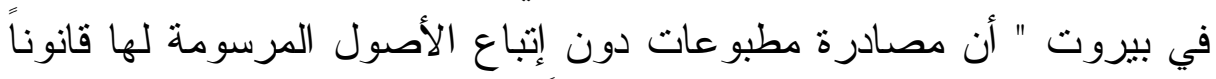

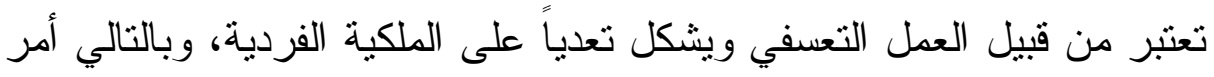

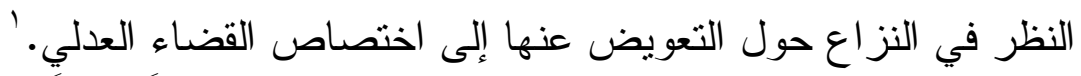

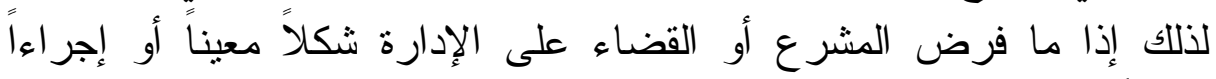

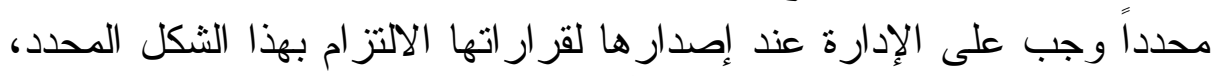

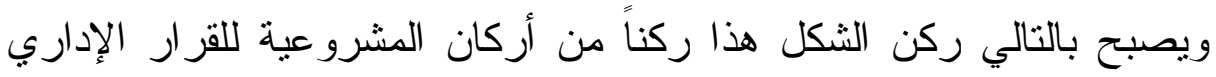

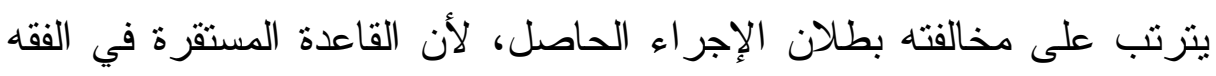
الإداري وقضائه تقضي بأن مخالفة تلك القواعد الثكلية تسنتبع بطلان

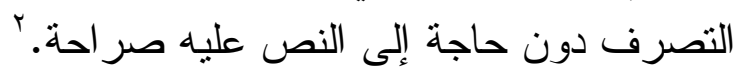

\section{الإطب الثالث}

\section{ركن الغاية والساطة التقديرية}

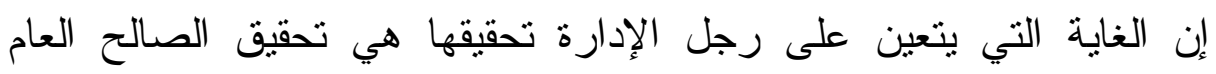

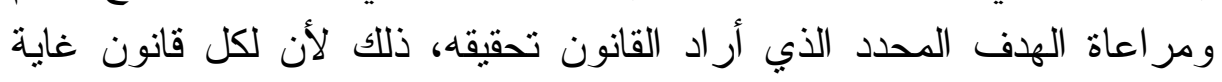

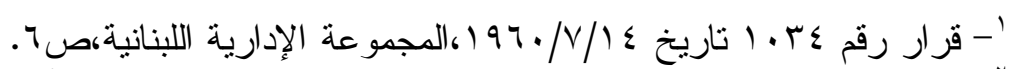

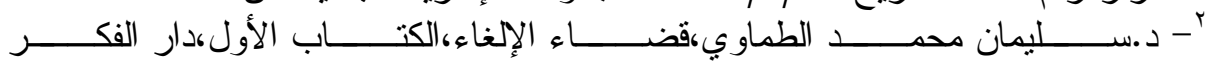

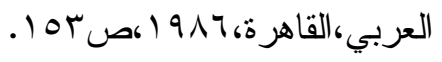


يسعى لتحقيقها وهي دائماً المصلحة العامة و التي تعتبر أساس تبرير منح

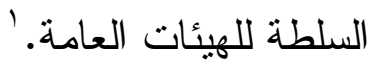
وأن القرار الإداري الذي لا تكون غايته تحقيق النفع العام يعد قراراً مشوباً

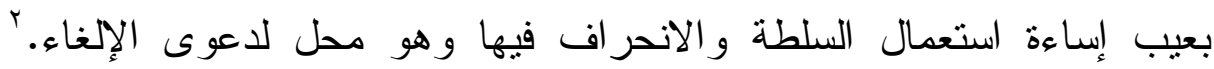

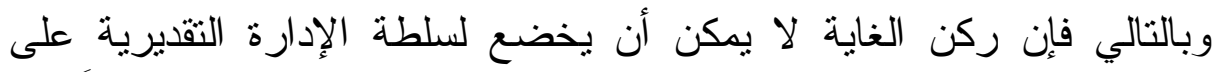

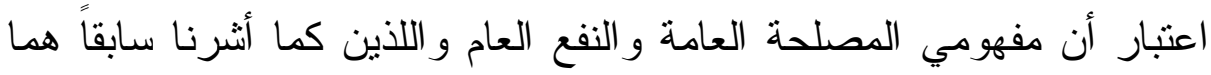

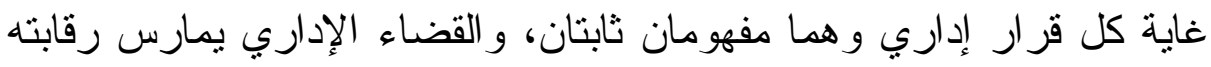

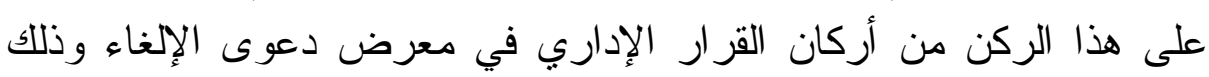

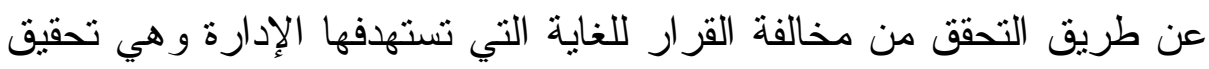
الصالح العام، ولقد أكد مجلس الدولن ملف الفرنسي رقابته لركن الغاية في القرار

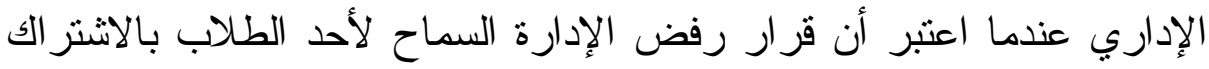

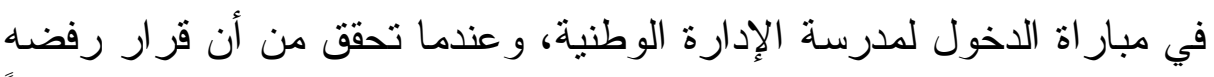
قد صدر لعلاقة الطالب بأحد الأحز اب المعارضة العقائدية يشكل الحر الفاً

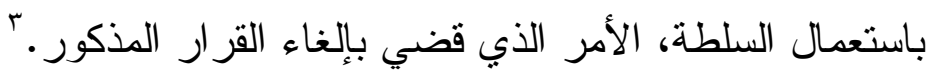

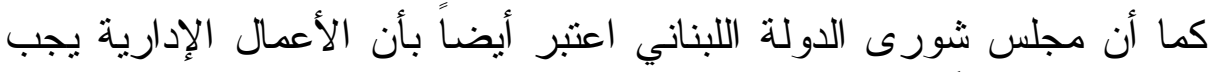

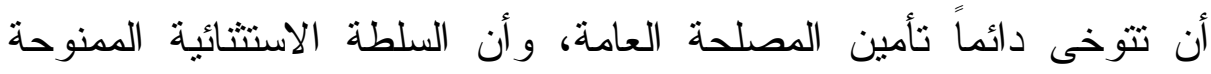
للإدارة ليست مز اجية أو كيفية، بل إن حقها يتمنل في تقدير ملائمة اتخاذ

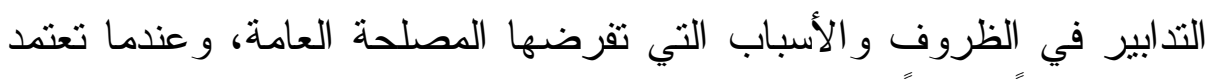

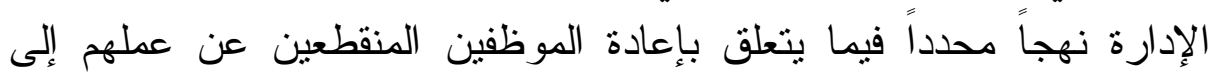

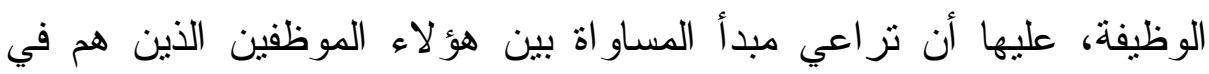

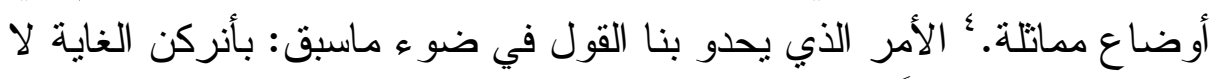
يمكن أن يكون محلاً لسلطة الإدارة التقديرية.

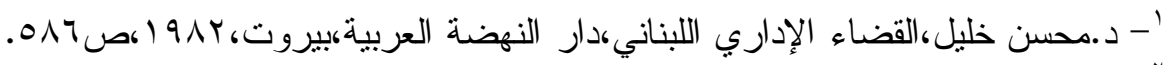

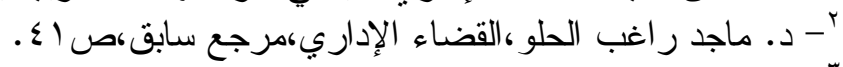

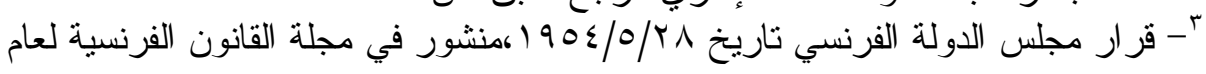

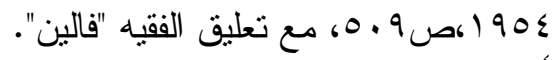

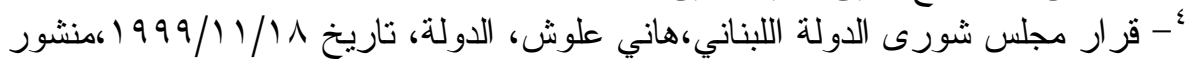

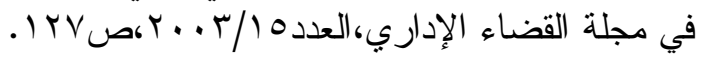




\section{الإhب الرابه}

\section{ركن السبب والسطالة التقديرية}

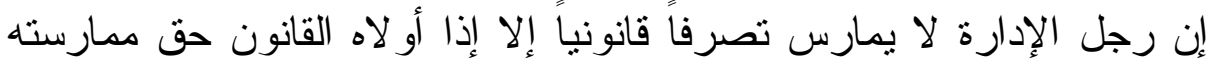

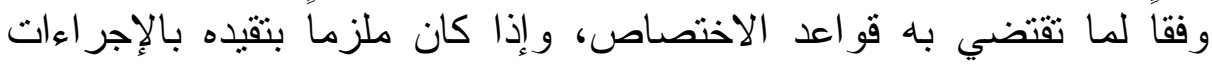

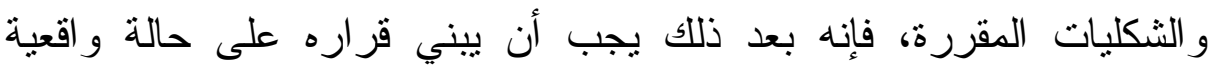

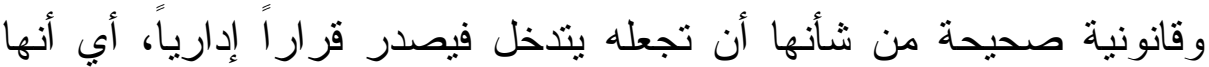

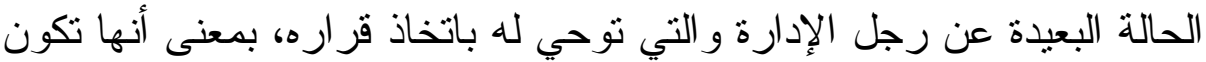
مستقلة عن رجل الإدارة من جهة وسابقة على العمل الإداري من جهة الإدة.

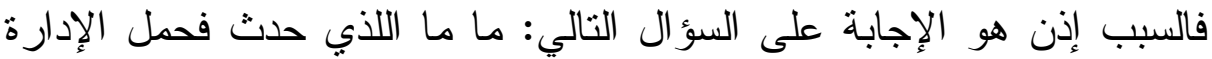

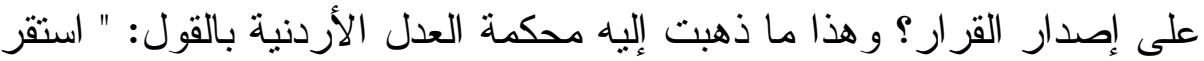

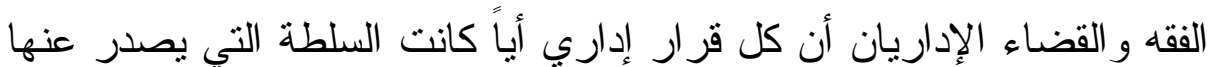

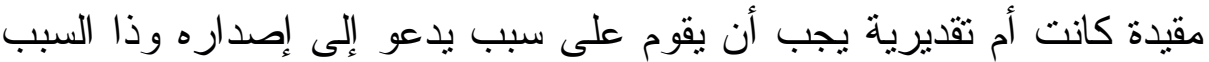

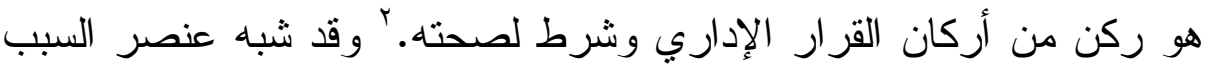

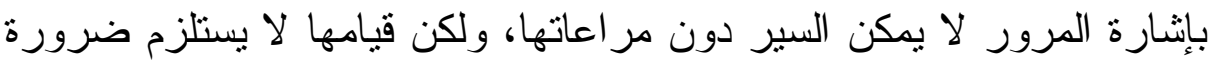

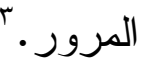

إذن السبب مجموعة العناصر القانونية والواقعية التي تقود الإدارة إلى القى القي التصرف و إصدار القرار الإداري، أي الأمر الذي يسبق القرار وليكة وليكون دافعاً

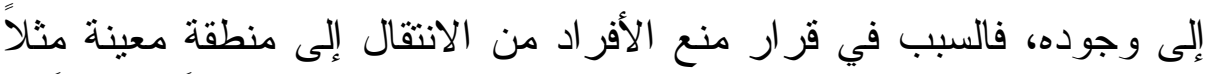

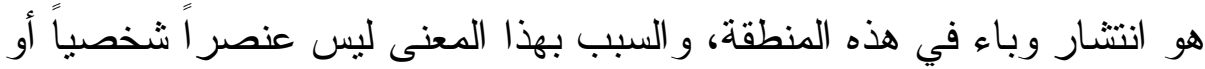

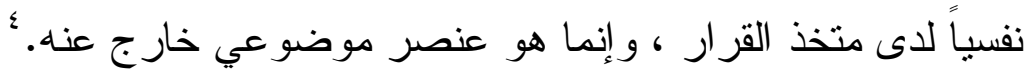

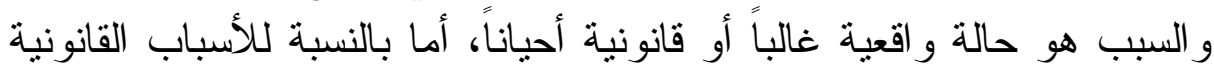

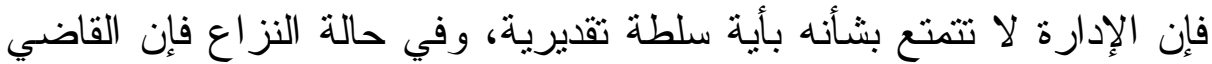
الإداري يمارس كامل رقابته على وجودها وشر عيتها وصحة تفسير الإدارة

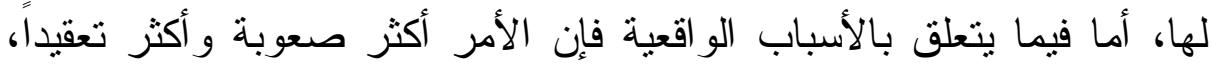
ولتحديد موقع السلطة التقديرية التي تتمتع بها الإدارة إز اء اله ركن السبب يتحنت

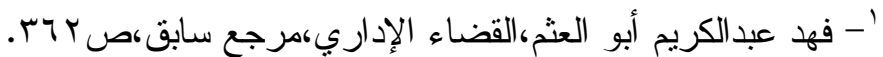

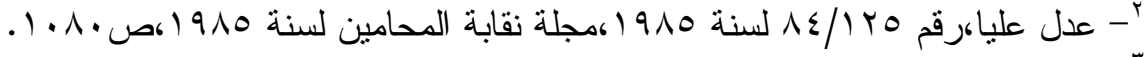

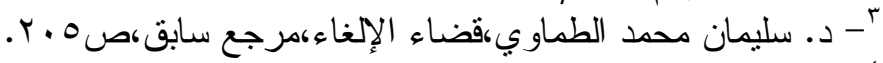

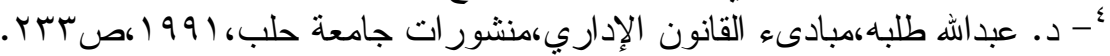


علينا بيان وتوضيح سلطات الإدارة إز اء هذا الركن من أركان القرار الإداري و التي لا تخرج عن الصور الثناث التالية:

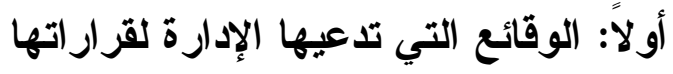
قد يكون مثار النزاع هو البحث في صحة قيام الوقائع التي بررت لإدارة للإدارة

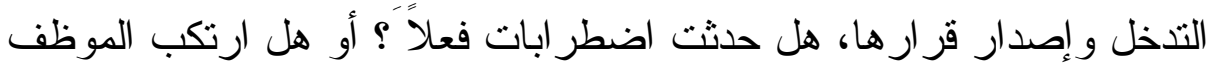

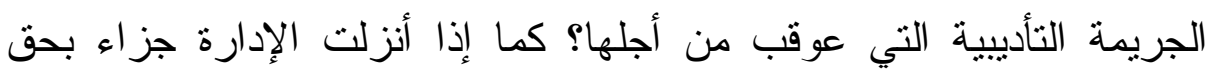
موظف بحجة ارتكابه لفعل خاطىء، في حين أن هذا الفعل لا وجود له.

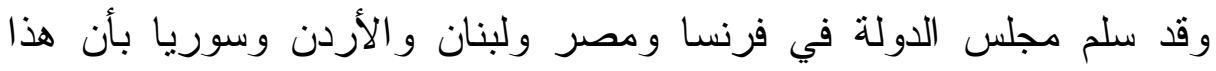

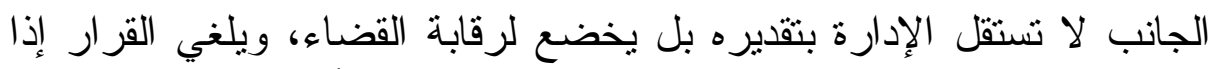

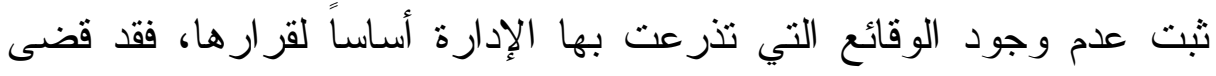

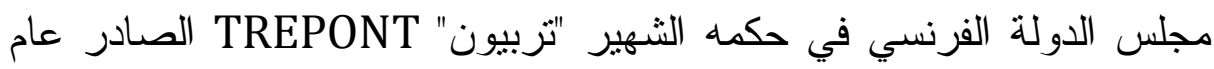

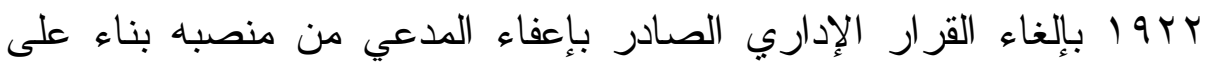

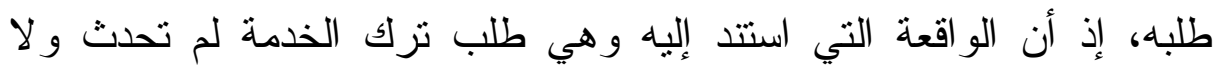

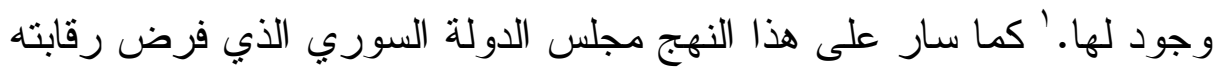

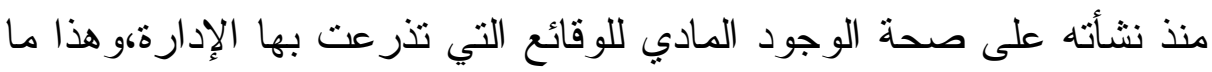

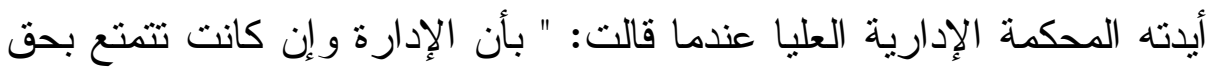

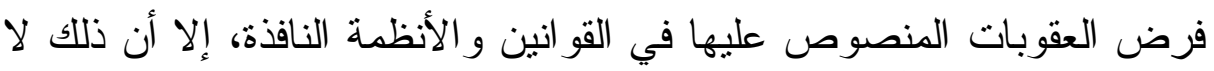

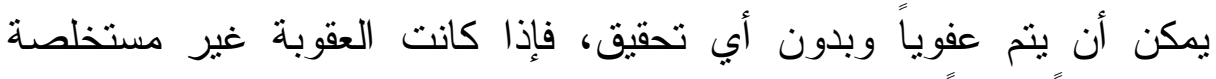

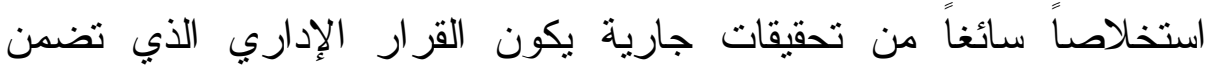

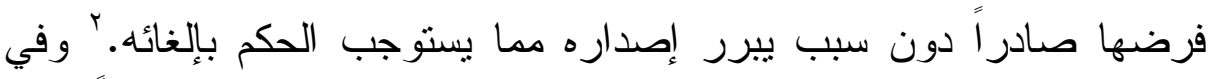

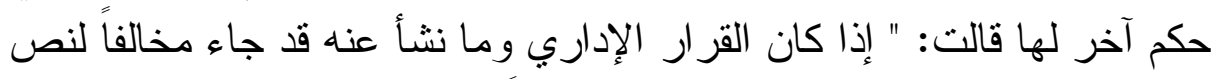

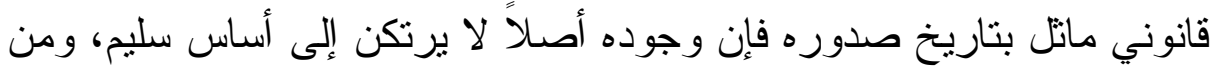

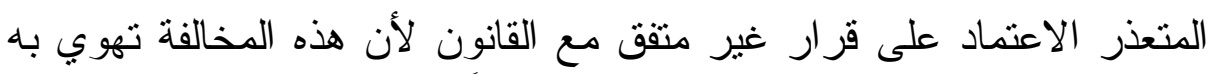

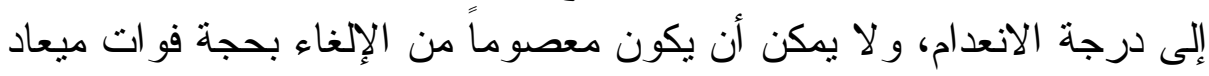

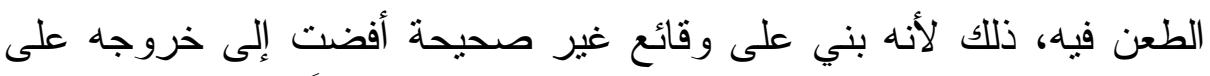

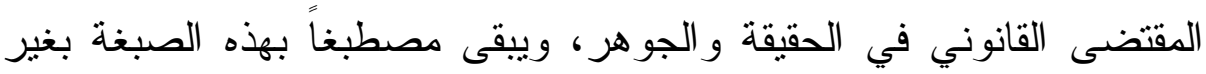

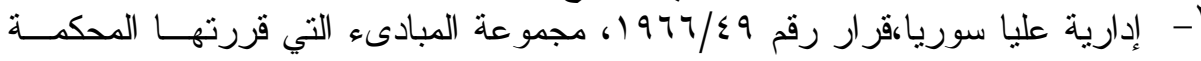

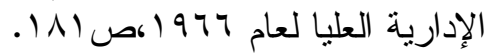


زوال مهما طال عليه الزمن".' وفي هذا الصدد تقول محكمة العدل العليا

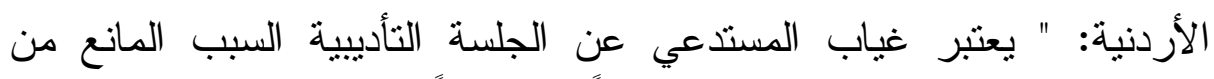

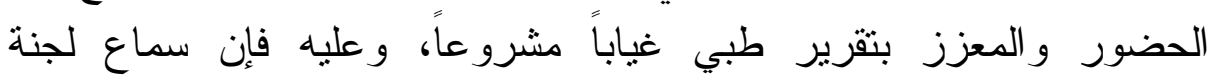

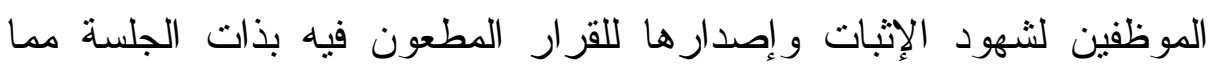

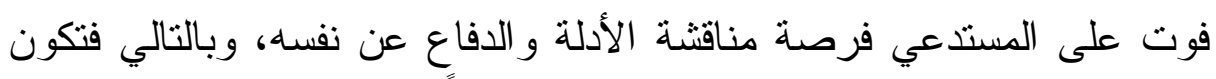

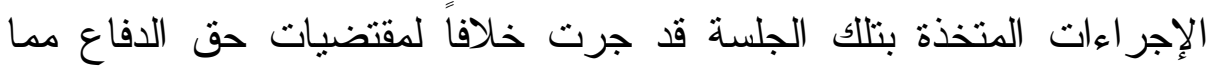

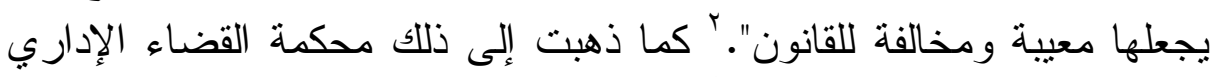

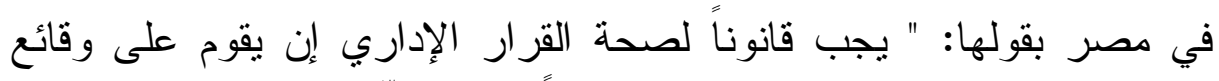

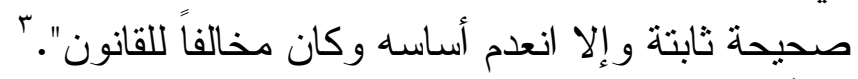

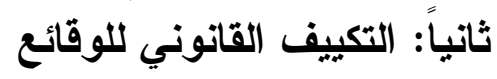

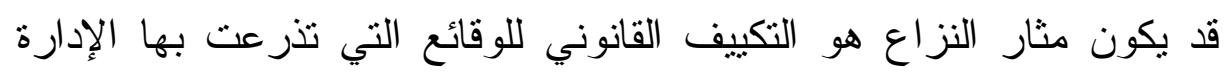

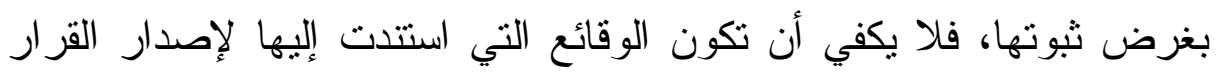

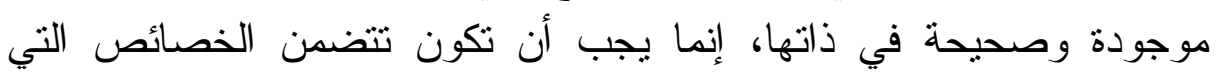

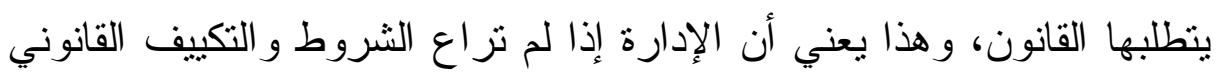

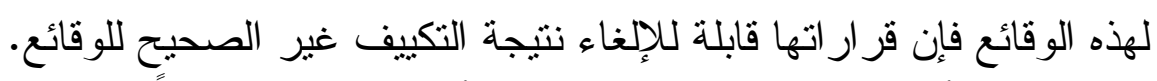

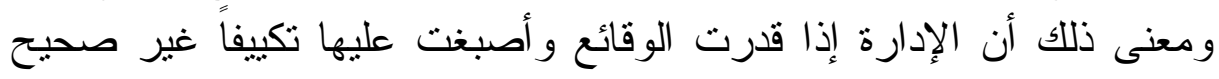

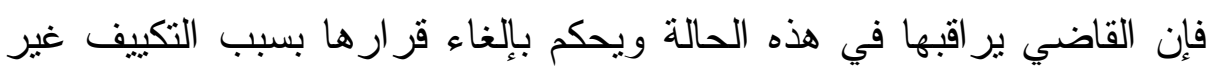

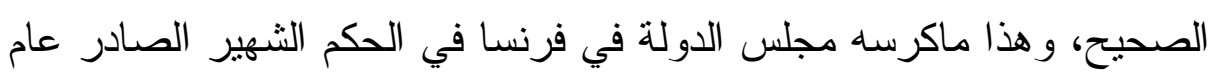

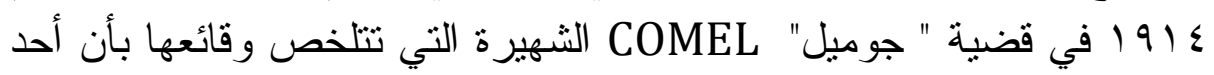

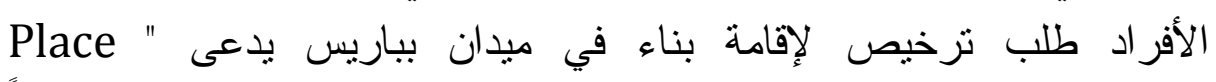
Peauvou

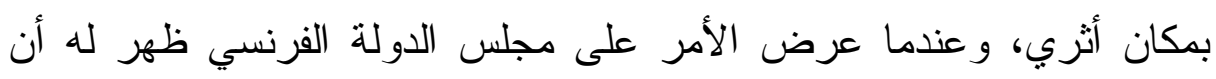

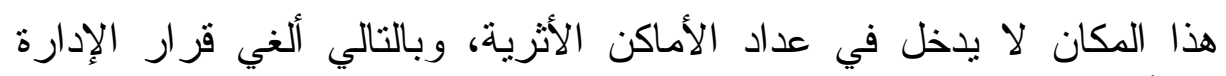

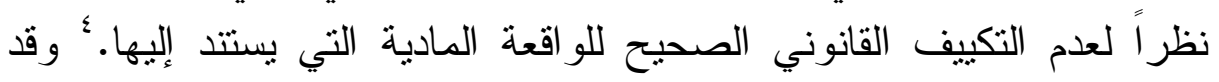

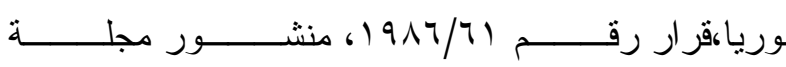

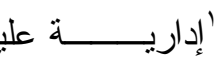

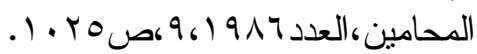

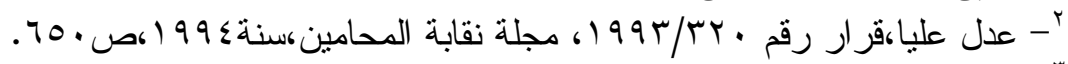

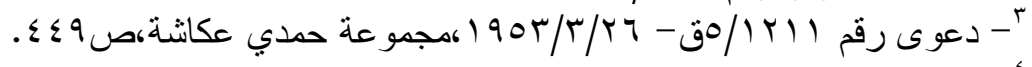

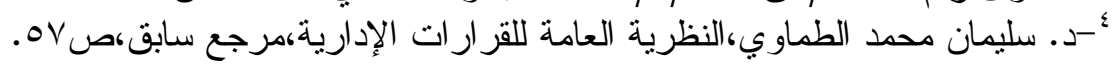


كرس ذللك أيضاً القضاء الإداري المصري، ففي حكم لمحكمة القضاء الإداري

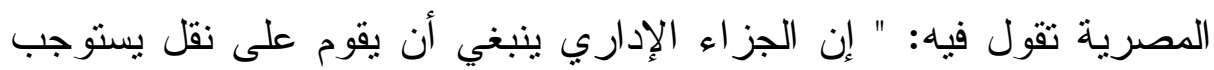

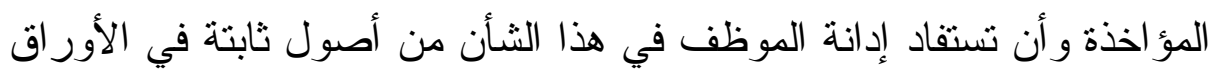

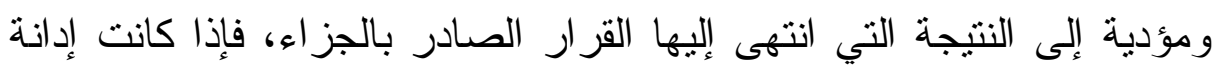

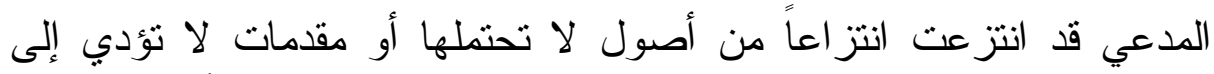

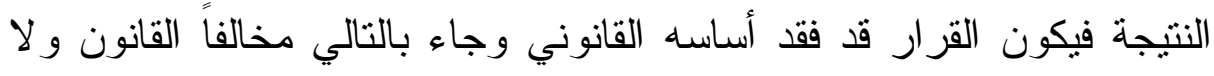
محل لمؤاخذة المدعي على تقديمه الثكوى إلى مصلحة الأموال المقررة دون

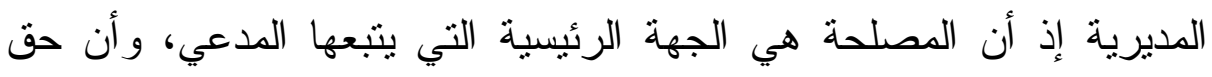
التظلم للجهات الرئيسية هو حق مشروع بنص صريح في قانون مجلس الد

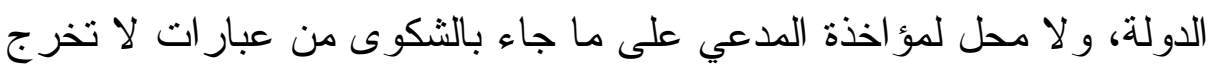

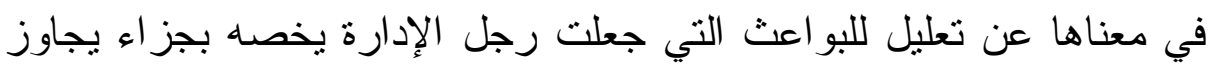

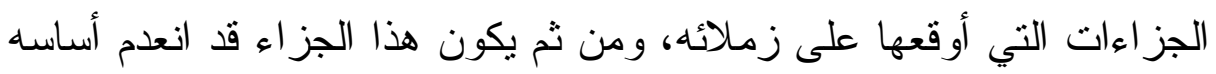

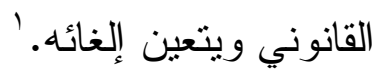

كما أن القضاء الإداري في الأردن نجده قد سار على نحو القضاء الإداري

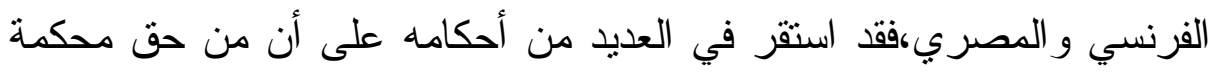
العدل العليا أن نر اقب صحة التكييف القانوني للوقائع المادية، وفيما إذا كانت

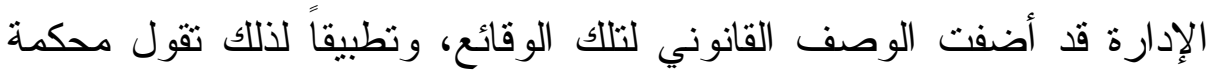

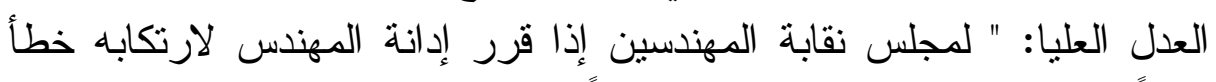

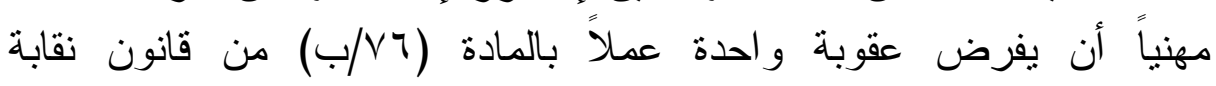
المهندسين، و عليه فإن فرض عقوبة شطب المكتب الهندسي العائد للمستدعي

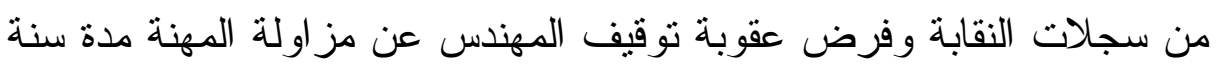

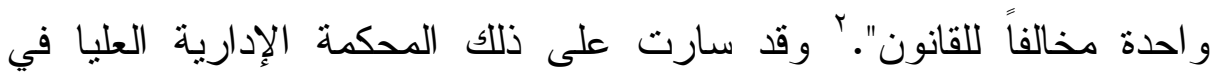

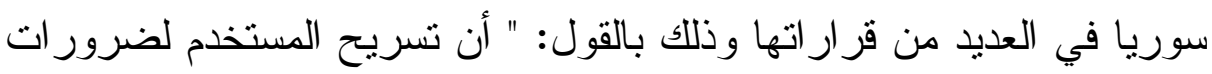
المصلحة العامة في تخفيض نفقات المؤسسة التي يعمل فيها، إذا ثبت للقضاء أن الإدارة لجأت بعد تسريح هذا المستخدم إلى ملء الثاغر الذي أحدثه

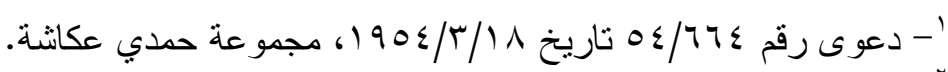
r - عدل عليا رقم

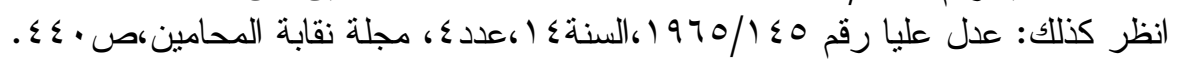

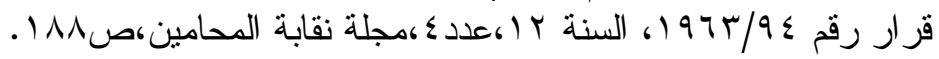


بتسريحه، فذلك يكثف عن عدم جدية السبب المتذرع به من أجل التسريح،

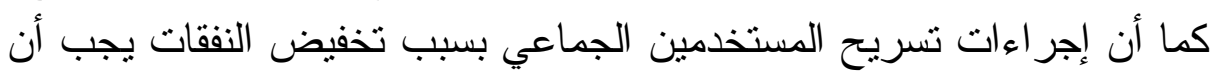

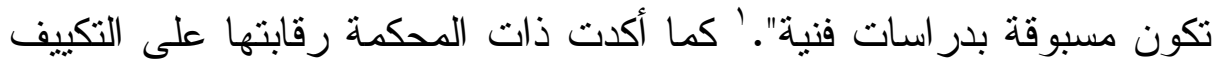

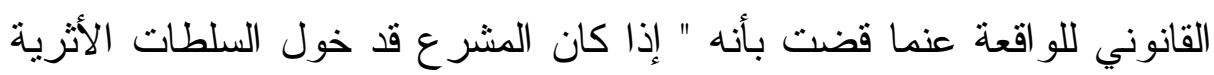

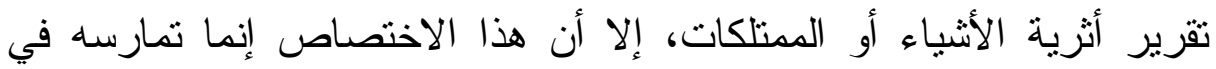

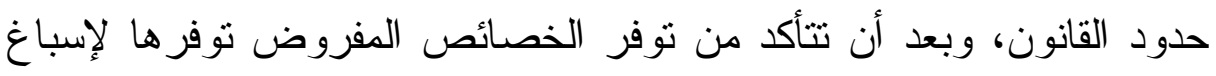
صفة الأثرية، وييقى للقضاء الإداري حق الرقابة على توفئ توفر الثروط القانونية

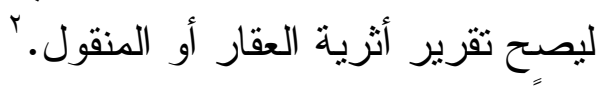

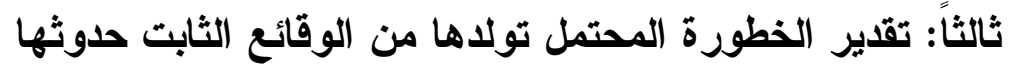

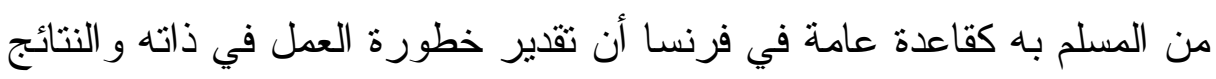

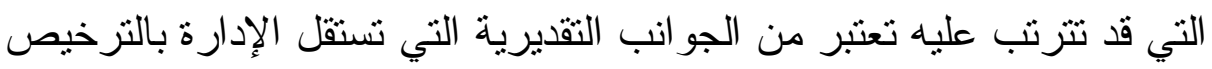

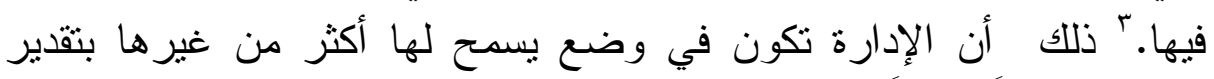
الأمور تقديراً سليماً، وما دام تقديرها يقوم في فلى فلى أساس من الوقائع الثابتة

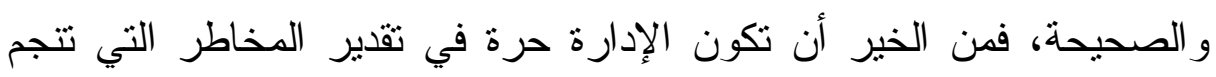

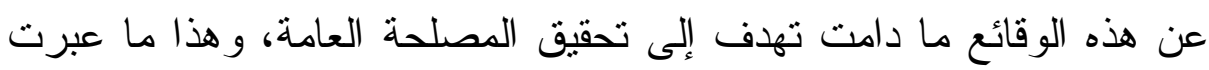

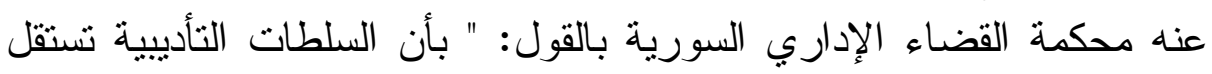

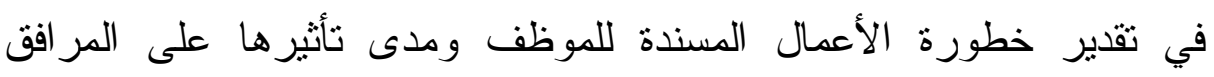
العامة"." وفي حكم آخر لها تقول: " أن تثبيث العامل الوكيل بموجب الأب أحكام

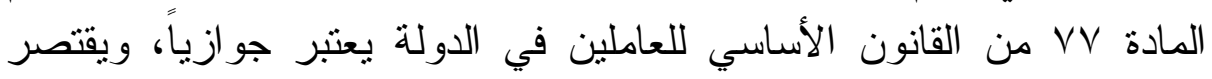

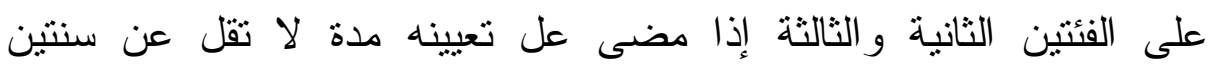

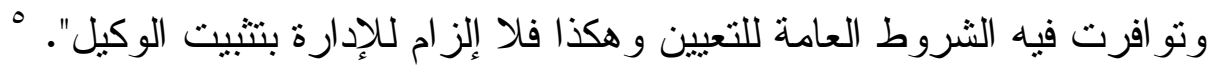

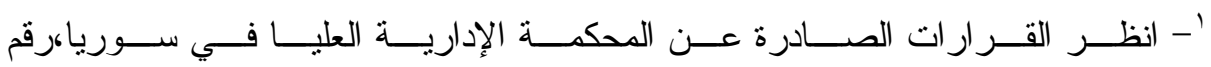

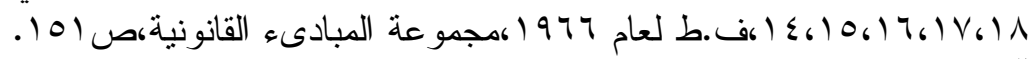

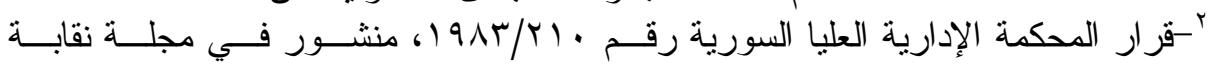

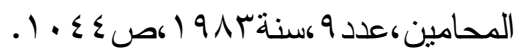

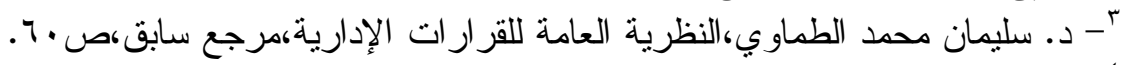

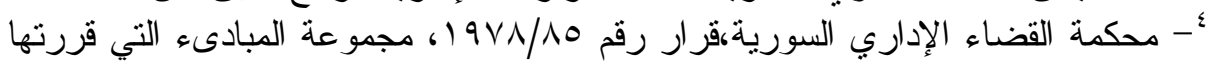

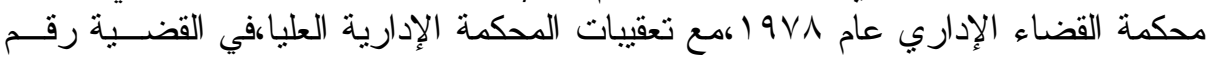

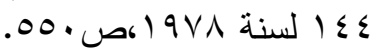

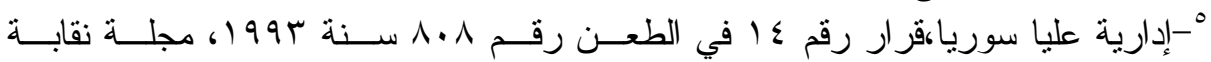

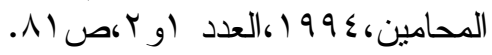


كما ذهبت المحكمة الإدارية العليا في مصر بالقول:" إن حق رئيس

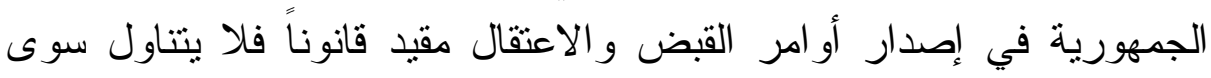

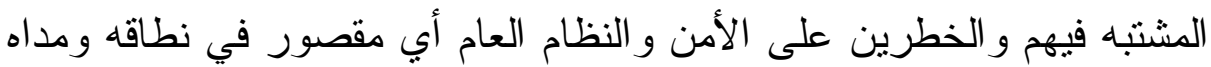

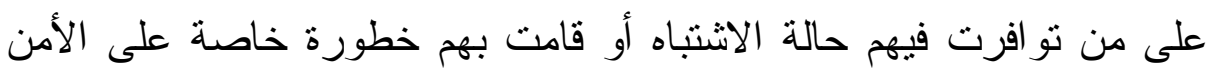

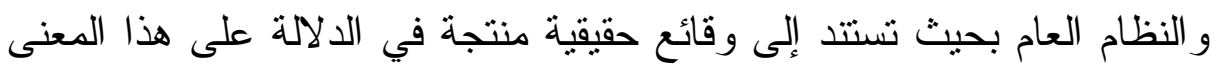

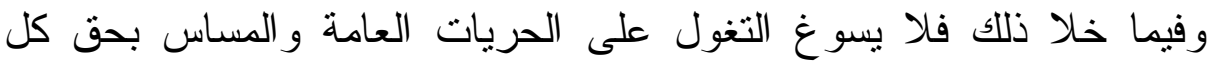

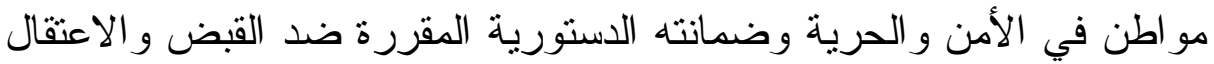
التعسفي فكر امة الفرد و وعزته وحريته دعامة لا غنه ونى عنها في مكانة الوطن وقوته وهييته، ومن حيث الثابت من الأوراق أن المدعي جرى اعتى اعتاله استتاداً

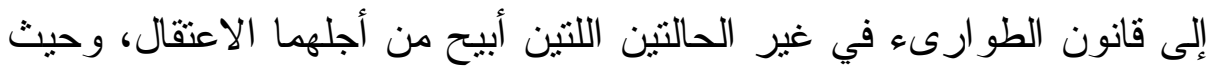

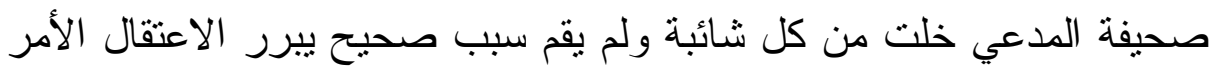

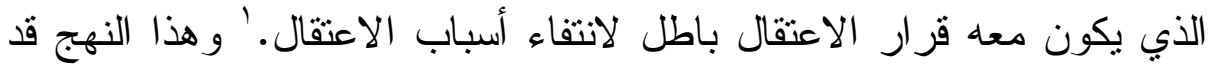

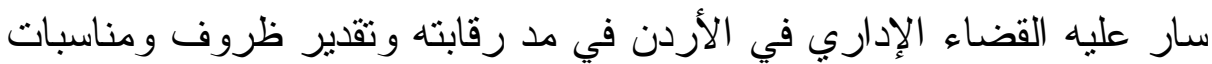

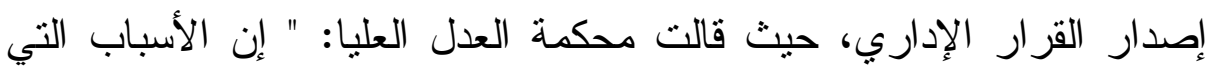

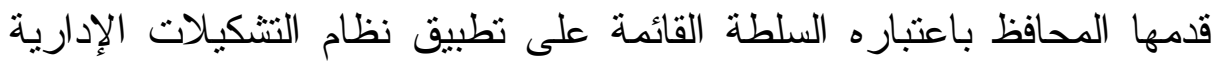

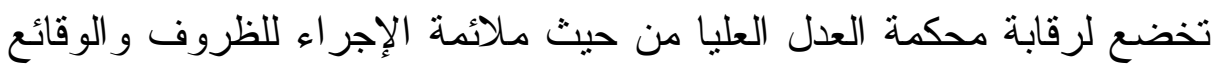

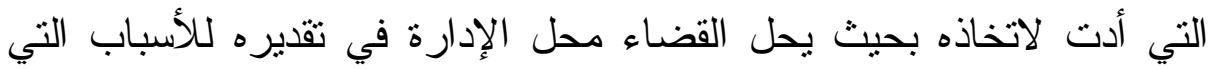

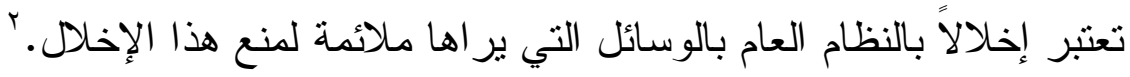

\section{الإلب الخامس}

\section{ركن الامل والسطبة التقديرية}

محل القرار الإداري هو موضوع القرار الإداري أو مضمون الأثر القانوني

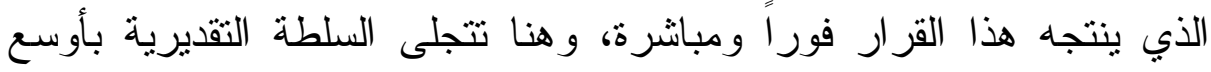
صورها، ذلك أن الإدارة بعد أن تتحقق من قيام الحالة الو اقعية التي تبرد

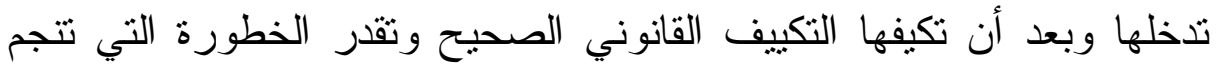
عنا ووقت تدخلها و الوسيلة التي تتخذها لمو اجهة حالة معينة تتمثل في ثلاثة

'طعن رقم TV0 و TV

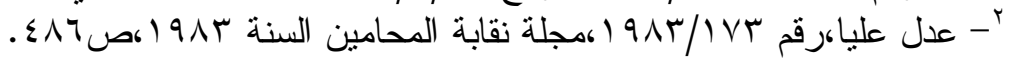




\section{أولاً: حرية الإدارة في أن تتلذل أو تمتنع}

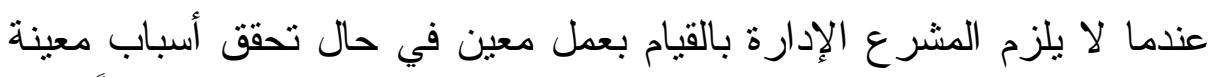

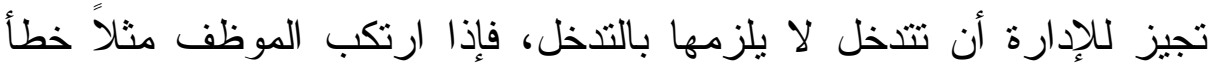

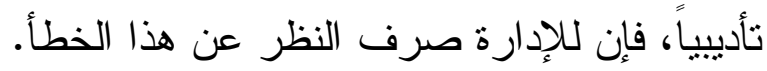

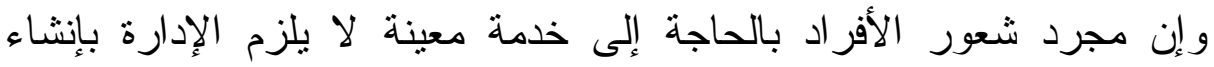

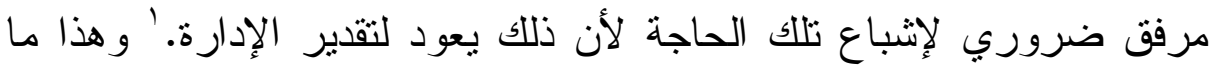

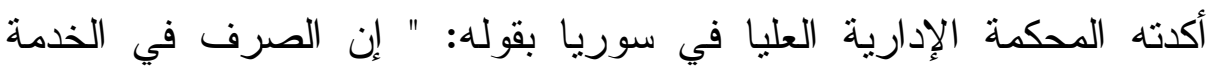

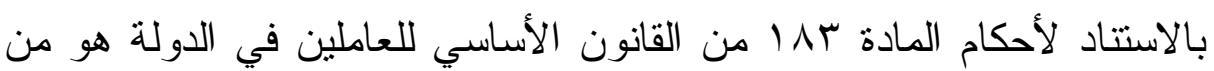

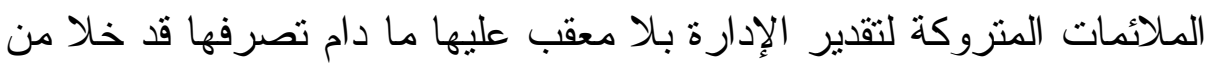

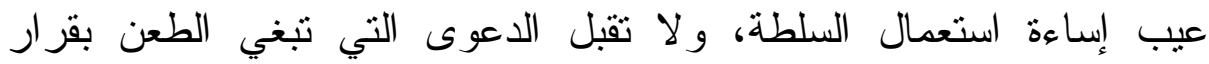

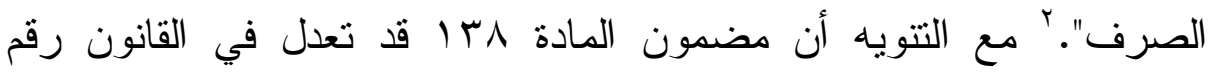

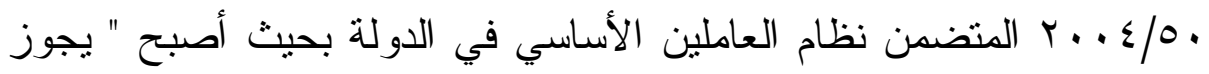

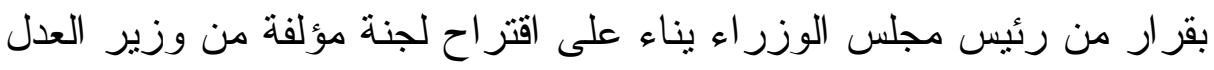

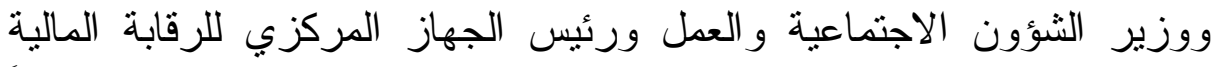

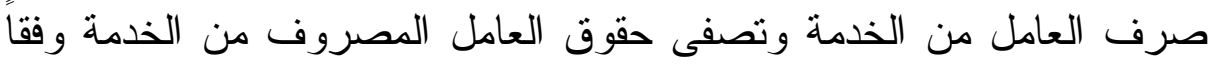

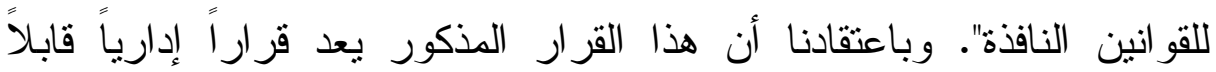

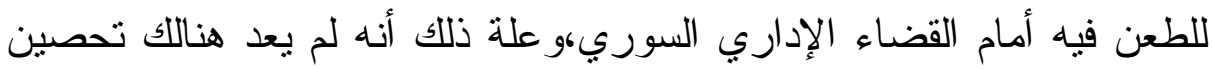
تشتريعي لمتل هذه القر ار ات كما كان عليه الحال الحال في القو انين السابقة.

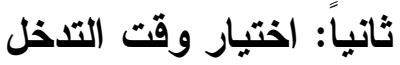

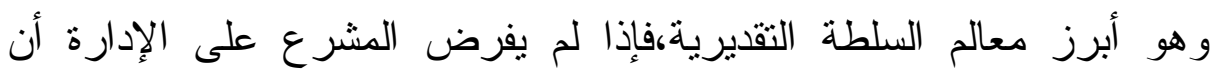

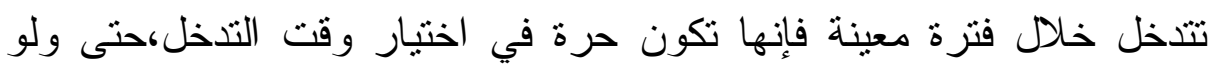

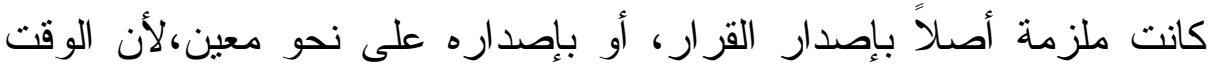

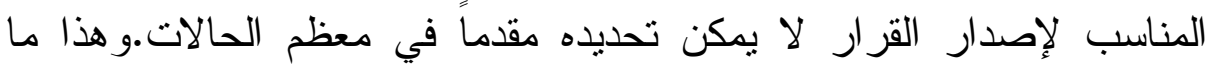

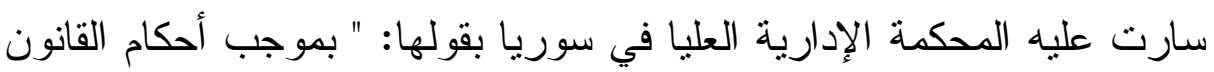

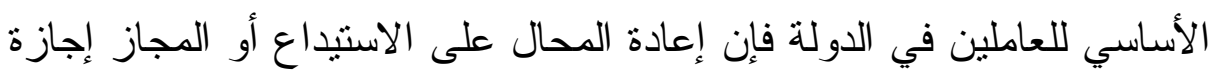

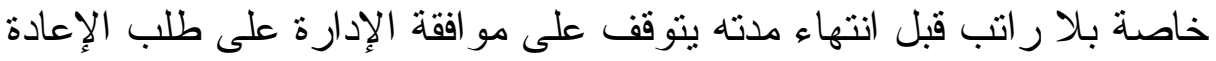

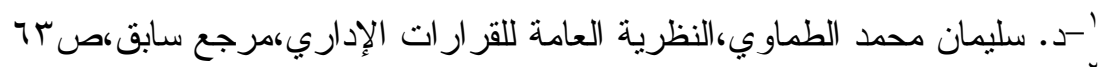

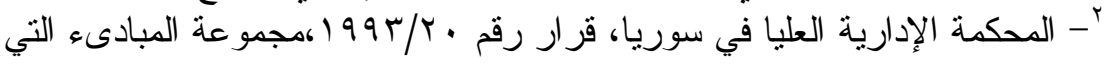

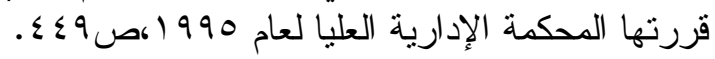


وتوفر الثاغر في الملاك.' غير أن حرية الإدارة في اختيار وقت التخخل ليست مطلقة، بل تتعرض لقيود مختلفة، فغالباً ما يحدد المشرع فرة فترة فئ معينة

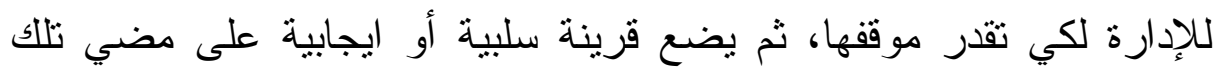

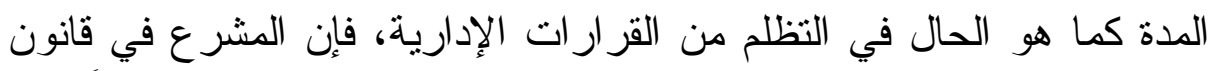
مجلس الدولة السوري رقم 1909/00 قد منح الإدارة مدة سنتين يوماً لكي

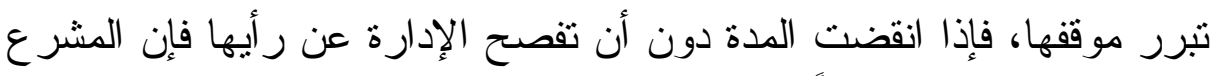

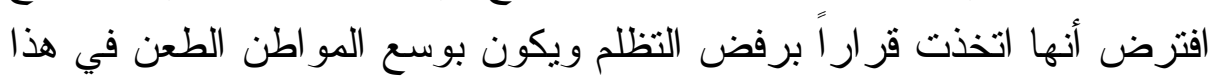
القر ار الضمني بدعوى تجاوز السلطة.

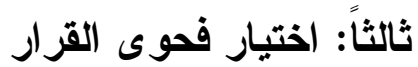

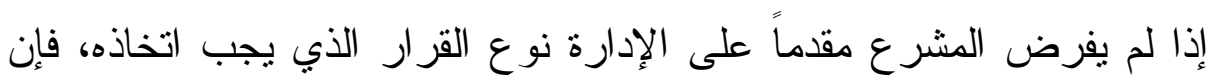

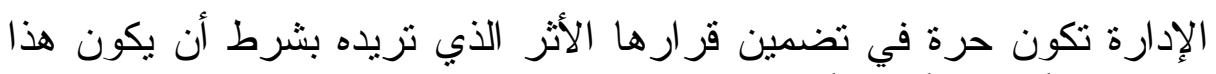
الأثز ممكناً وجائز اً قانوناً. فرجل الإدارة يتمتع بسلطة تقديرية واسعة في هذا المجال، فكلما كانت قاعدة فئان

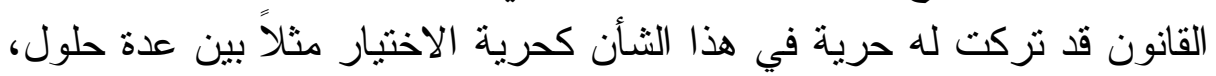

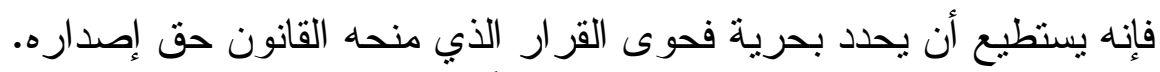

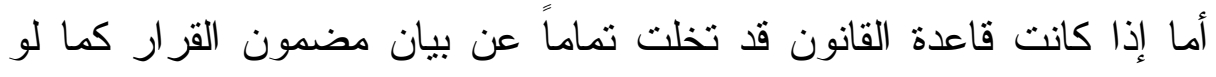

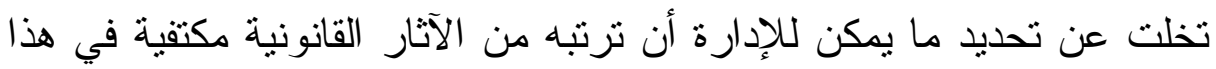

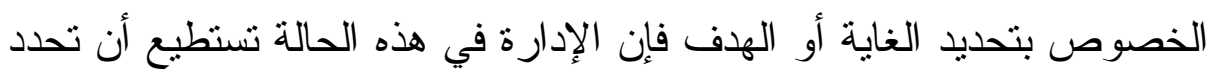

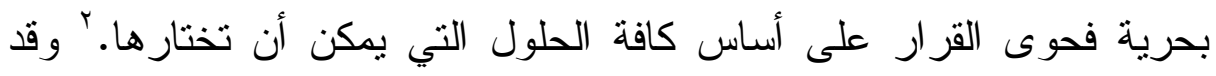

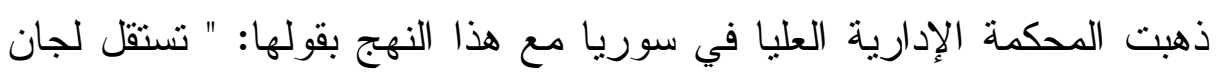

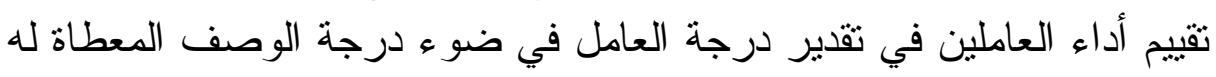

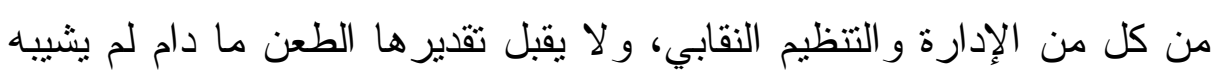
عيب الانحر اف أو إساءة استعمال السلطة.

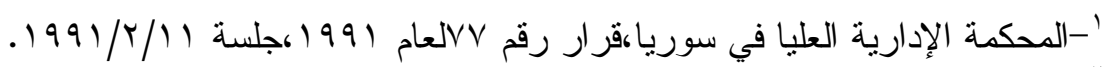

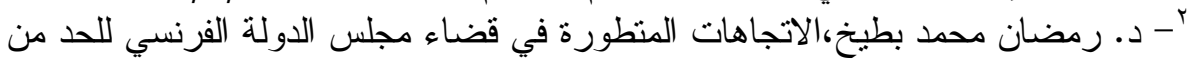

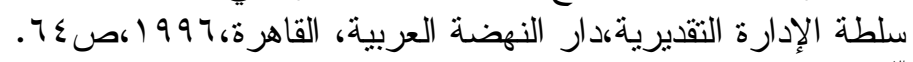

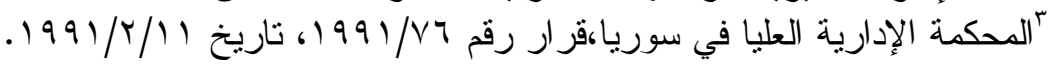


خلصت الدراسة إلى أن الإدارة تتمتع بسلطة تقديرية واسعة فيما يتعلق بركن

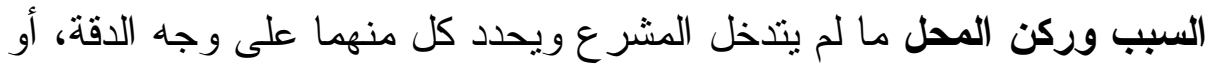
يتذخل القاضي ويفرض رقابته على اختيار السبب و المحل لاعتبار ات يقدرها بنفسه. أما ركن الاختصاص فلا نوجد سلطة تقديرية للإدارة فيه، لأن الإدارة إما أن

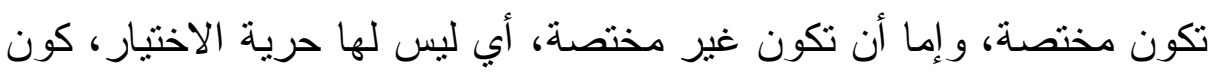
الاختصاص أصلاً محدد بالقانون.

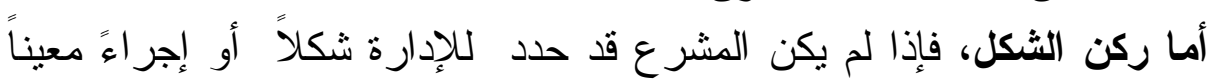

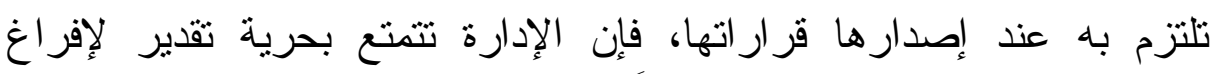

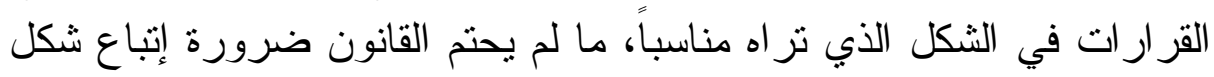
خاص بالنسبة لقر ار معين. أما ركن الغاية، فإنه لا يمكن أن يكون محلاً للسلطة التقديرية، لأن سلطة

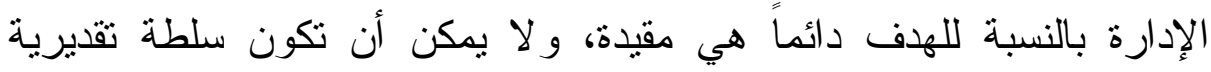

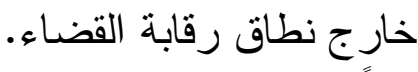

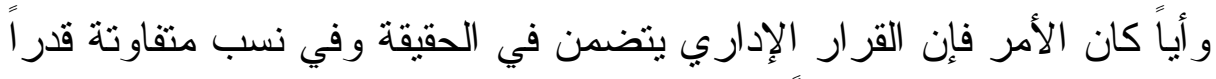

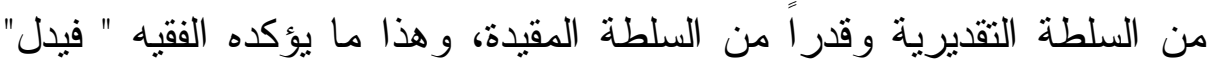

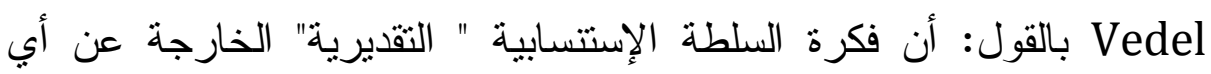

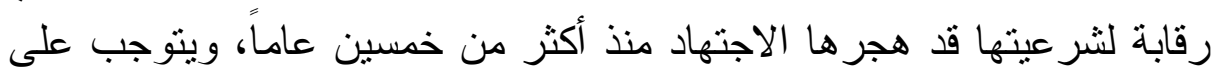

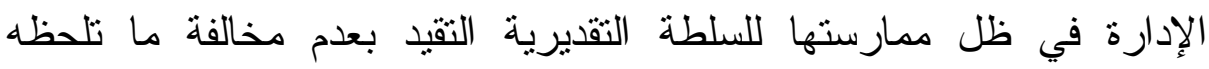

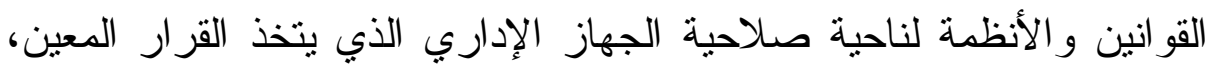

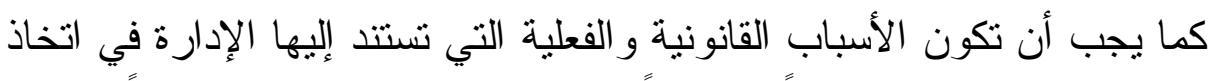

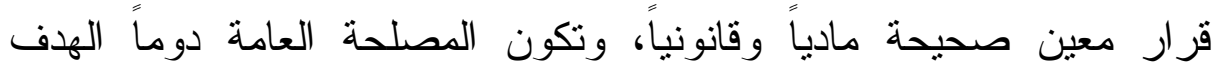
النهائي لعمل الإدارة. كما أن مجلس الدولة السوري لم ينهج نهج القضاء القهاء الفرنسي والأردني

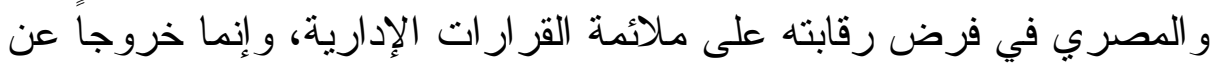

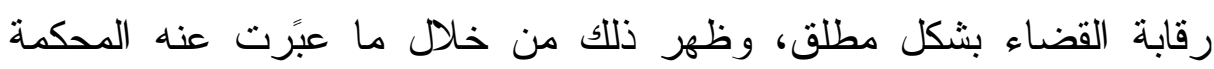

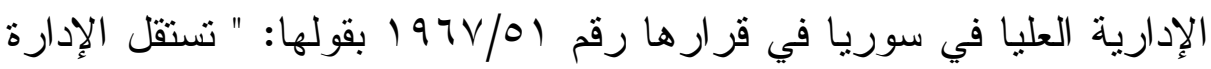

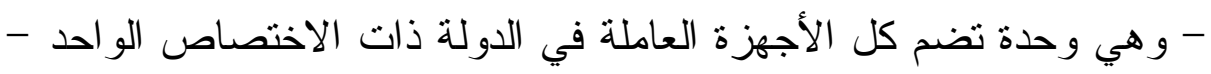


في تقدير ملأئمة تعيين أي فرد لأي وظيفة في أي مرفق من مر افق الدولة

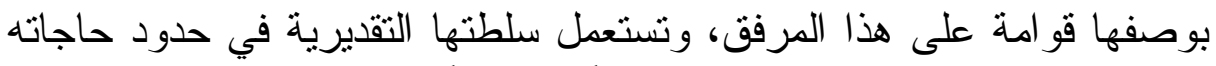

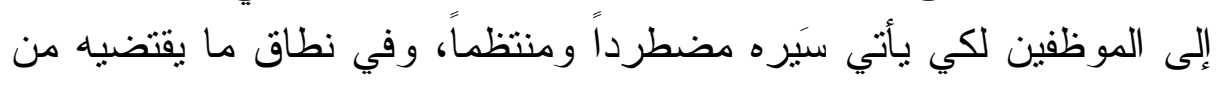

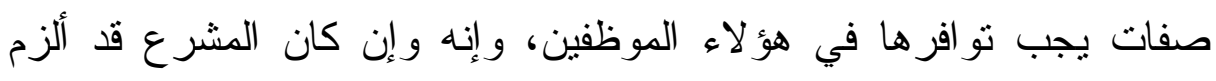

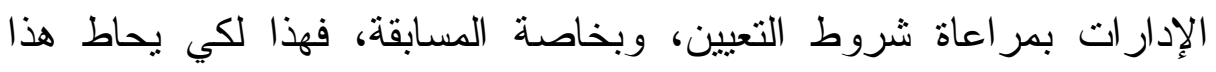

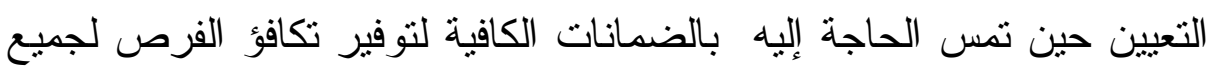

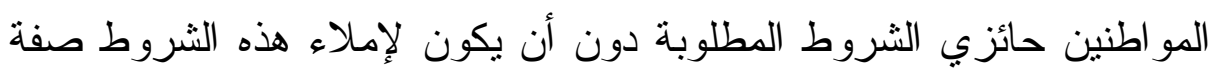

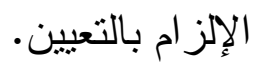

1 - يجب أن تخضع السلطة التقديرية للإدارة في ركن السبب لرقابة القضاء الإداري، وذللك لضمان عدم تعسف الإدارة في استخدام سلطتها التقديرية.

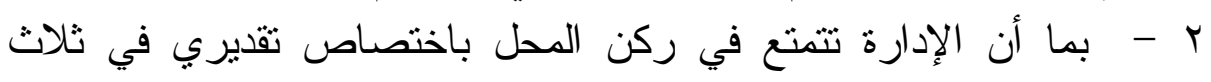

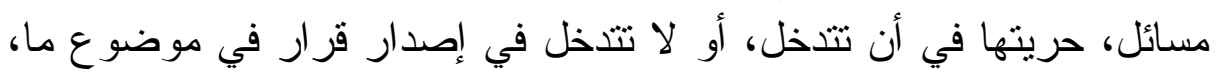

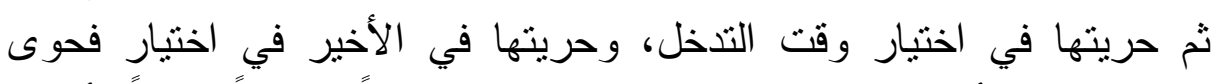

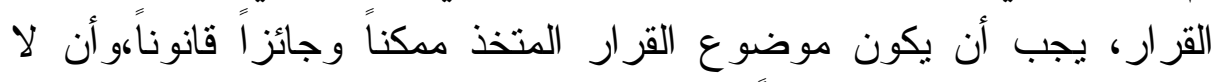

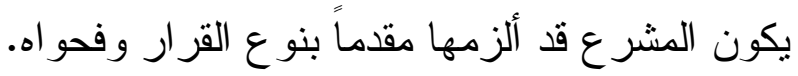

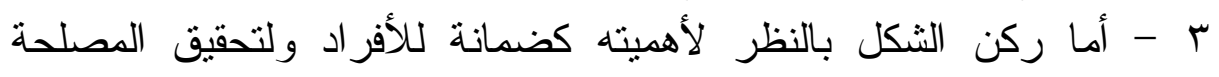

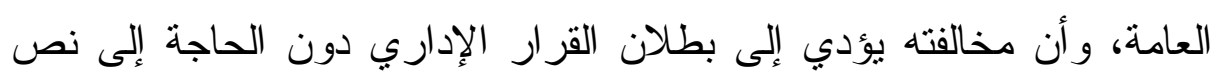

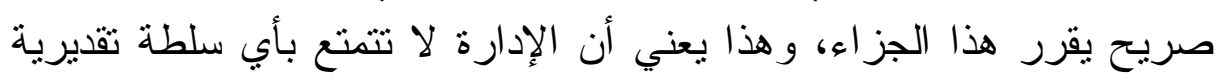

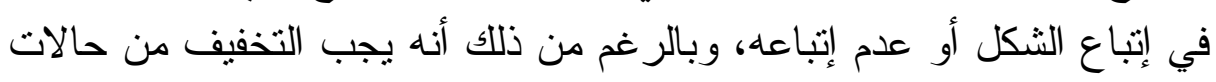

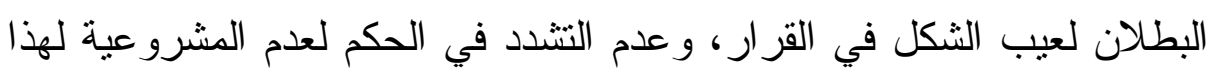

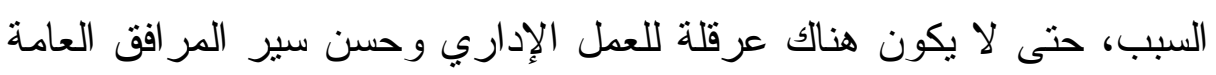

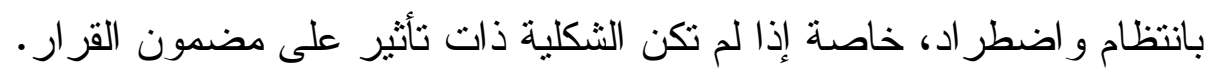

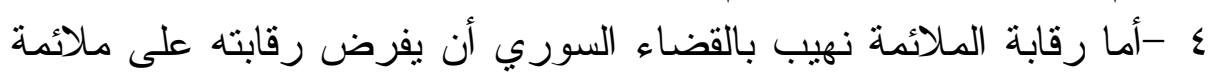
القر ار ات الإدارية شأنه في ذلك شأن القضاء الفرنسي والأرداء ناءني و المصري. 
